\title{
Further Advances in Optimizing (2-Phenylcyclopropyl)methylamines as Novel Serotonin 2C Agonists: Effects on Hyperlocomotion, Prepulse Inhibition, and Cognition Models
}

\author{
Jianjun Cheng, ${ }^{\dagger}$ Patrick M. Giguere, ${ }^{\ddagger}$, II Claire M. Schmerberg, ${ }^{\S, \#}$ Vladimir M. Pogorelov, ${ }^{\S}$ \\ Ramona M. Rodriguiz, ${ }^{\S}$ Xi-Ping Huang, ${ }^{\ddagger} \mathrm{Hu}$ Zhu, ${ }^{\ddagger}$ John D. McCorvy, William C. Wetsel, ${ }^{\S}$ \\ Bryan L. Roth, ${ }^{\ddagger}$ and Alan P. Kozikowski* ${ }^{\dagger}$ \\ ${ }^{\dagger}$ Drug Discovery Program, Department of Medicinal Chemistry and Pharmacognosy, College of Pharmacy, University of Illinois at \\ Chicago, Chicago, Illinois 60612, United States \\ ${ }^{\ddagger}$ National Institute of Mental Health Psychoactive Drug Screening Program, Department of Pharmacology and Division of Chemical \\ Biology and Medicinal Chemistry, University of North Carolina Chapel Hill Medical School, Chapel Hill, North Carolina 27599, \\ United States \\ ${ }^{\S}$ Department of Psychiatry and Behavioral Sciences, Mouse Behavioral and Neuroendocrine Analysis Core Facility, \\ Duke University Medical Center, Durham, North Carolina 27710, United States
}

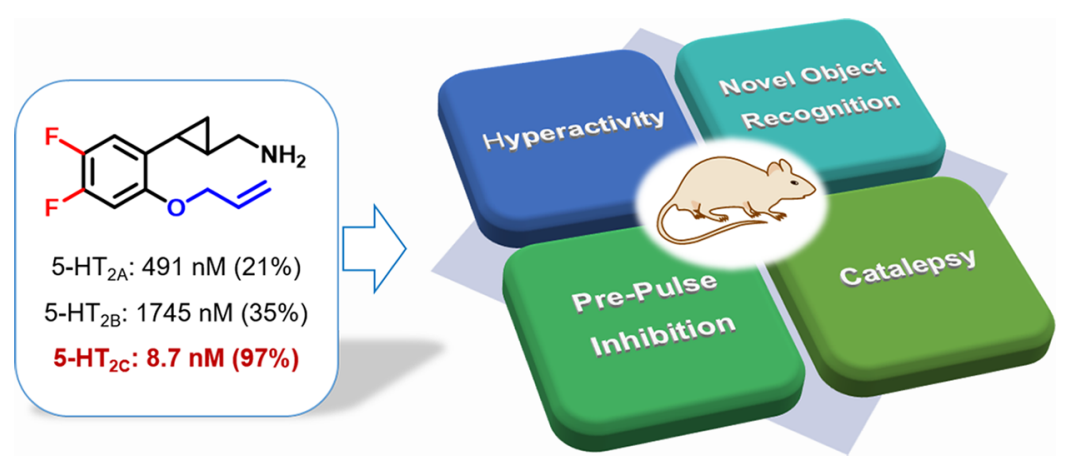

\begin{abstract}
A series of novel compounds with two halogen substituents have been designed and synthesized to further optimize the 2-phenylcyclopropylmethylamine scaffold in the quest for drug-like 5- $\mathrm{HT}_{2 \mathrm{C}}$ agonists. Compound (+)-22a was identified as a potent $5-\mathrm{HT}_{2 \mathrm{C}}$ receptor agonist, with good selectivity against the $5-\mathrm{HT}_{2 \mathrm{~B}}$ and the $5-\mathrm{HT}_{2 \mathrm{~A}}$ receptors. ADMET assays showed that compound (+)-22a possessed desirable properties in terms of its microsomal stability, and CYP and hERG inhibition, along with an excellent brain penetration profile. Evaluation of (+)-22a in animal models of schizophrenia-related behaviors revealed that it had a desirable activity profile, as it reduced $d$-amphetamine-stimulated hyperlocomotion in the open field test, it restored $d$-amphetamine-disrupted prepulse inhibition, it induced cognitive improvements in the novel object recognition memory test in NR1-KD animals, and it produced very little catalepsy relative to haloperidol. These data support the further development of (+)-22a as a drug candidate for the treatment of schizophrenia.
\end{abstract}

\section{INTRODUCTION}

Schizophrenia is a severe mental disease that affects $1 \%$ of the population in the US and more than 21 million people worldwide. ${ }^{1}$ It is a disease of complex etiology with likely more than 100 genetic loci and unspecified nongenetic contributing factors. ${ }^{2,3}$ At least three types of symptoms exemplify schizophrenia: positive, negative, and cognitive. The available antipsychotic drugs are effective against positive symptoms while having minimal effects on cognitive and negative symptoms. ${ }^{4,5}$

The $5-\mathrm{HT}_{2 \mathrm{C}}$ receptor has recently been identified as a promising drug target for the treatment of a variety of central nervous system (CNS) disorders, including obesity, schizophrenia, and substance abuse. ${ }^{6,7}$ Lorcaserin (1, Figure 1) and vabicaserin (2) are two representative $5-\mathrm{HT}_{2 \mathrm{C}}$ agonists that have been developed and studied in clinical trials for these indications. Lorcaserin is the first-in-class 5- $\mathrm{HT}_{2 \mathrm{C}}$ agonist that has won FDA approval in 2012 for the treatment of obesity, and a clinical trial to evaluate its use in smoking cessation has also been completed, with the results remaining to be disclosed. ${ }^{8}$ Vabicaserin was studied in clinical trials for the treatment of acute schizophrenia, in which it demonstrated significant therapeutic effects and achieved a proof-of-concept, but it failed to meet the primary efficacy objective. ${ }^{9,10}$ For many years it has been appreciated that $5-\mathrm{HT}_{2 \mathrm{C}}$

Received: July 22, 2015

Published: December 24, 2015 


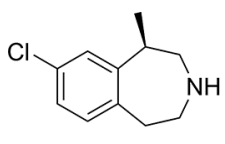

1

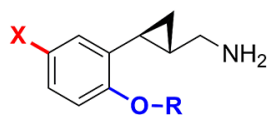

3: $\mathrm{X}=\mathrm{Cl}, \mathrm{R}=2$-fluoroally

4. $\mathrm{X}=\mathrm{Cl}, \mathrm{R}=2$-fluoroethyl

5: $\mathrm{X}=\mathrm{F}, \mathrm{R}=$ allyl

6: $X=F, R=2$-fluoroethyl

Figure 1. Structures of lorcaserin (1), vabicaserin (2), and compounds $3-6$.

receptor function might be altered in schizophrenia and that the $5-\mathrm{HT}_{2 \mathrm{C}}$ antagonist activity of certain atypical antipsychotic drugs might be associated with weight gain and adverse metabolic consequences. ${ }^{11-14}$ Advantages of the $5-\mathrm{HT}_{2 \mathrm{C}}$ receptor as a drug target for treating schizophrenia and related disorders include the following: (1) activation of $5-\mathrm{HT}_{2 \mathrm{C}}$ receptors specifically decreases mesolimbic dopamine release without affecting nigrostriatal dopamine; ${ }^{15}$ thus, it is predicted to have antipsychotic efficacy while causing few extrapyramidal symptoms (EPS); (2) $5-\mathrm{HT}_{2 \mathrm{C}}$ agonists are known to induce weight loss, and thus such drugs should lack the undesired side effect of weight gain and related metabolic disorders, which have been associated with most current antipsychotic drugs. ${ }^{14,16}$ Additionally, activation of the $5-\mathrm{HT}_{2 \mathrm{C}}$ receptor has been demonstrated to counter cognitive deficits induced by $N$-methyl-D-aspartate (NMDA) antagonism, ${ }^{17}$ as well as to overcome cognitive deficits in animals bearing the human tryptophan hydroxylase 2 (Tph2) loss of function mutation. ${ }^{18}$ Therefore, developing safe $5-\mathrm{HT}_{2 \mathrm{C}}$ agonists for the treatment of schizophrenia could potentially address the cognitive deficits associated with this disease with fewer EPS and a lower risk of causing weight gain.

The greatest challenge for developing $5-\mathrm{HT}_{2 \mathrm{C}}$ receptor agonists is their selectivity against the other two related receptors of the $5-\mathrm{HT}_{2}$ subfamily, namely $5-\mathrm{HT}_{2 \mathrm{~A}}$ and $5-\mathrm{HT}_{2 \mathrm{~B}}$. Activation of $5-\mathrm{HT}_{2 \mathrm{~A}}$ receptors in the $\mathrm{CNS}$ has been reported to be associated with hallucinogenic effects, ${ }^{19}$ while activation of $5-\mathrm{HT}_{2 \mathrm{~B}}$ receptors in the periphery produces valvulopathy and pulmonary hypertension as has been observed with the use of dexfenfluramine. $^{7,20}$ The FDA-approved drug lorcaserin was reported to have 100 -fold selectivity for $5-\mathrm{HT}_{2 \mathrm{C}}$ relative to the $5-\mathrm{HT}_{2 \mathrm{~B}}$ subtype; however, it possesses full agonist activity at $5-\mathrm{HT}_{2 \mathrm{~B}}$ with moderate potency $\left(\mathrm{EC}_{50}=943 \pm 90 \mathrm{nM}, E_{\max }=\right.$ $100 \%),{ }^{21}$ and lorcaserin was reported to cause a higher incidence of cardiac valve disorders in clinical trials compared to the placebo group. ${ }^{22}$ We previously reported on a series of novel compounds that have excellent selectivity for $5-\mathrm{HT}_{2 \mathrm{C}}$ receptors which are composed of a 2-phenylcyclopropylmethylamine scaffold. ${ }^{23-26}$ Among the reported compounds, analogues 3-6 (Figure 1) were identified to possess moderate to excellent pharmacological profiles, and they are now undergoing further evaluation in preclinical models. ${ }^{23}$

Due to the relatively small structural scaffold of the 2-phenylcyclopropylmethylamines and the very strict steric limitations applying to these compounds as revealed by previous structureactivity relationship (SAR) studies, adding a second halogen atom to the benzene ring appeared to offer a practical approach to further enhancing ligand potency and possibly metabolic stability. Decoration of the aromatic ring of a drug candidate with halogen atoms, especially fluorine and chlorine, has been used extensively in medicinal chemistry. ${ }^{27}$ The role of halogen substituents in enhancing ligand potency as well as in optimizing pharmacokinetic properties is well-known. The incorporation of multihalogen atoms is exemplified by drugs not only for peripheral diseases such as sitagliptin $(7)^{28}$ and crizotinib $(8)^{29}$ but also for CNS drugs such as aripiprazole $(9)^{30}$ (Figure 2).

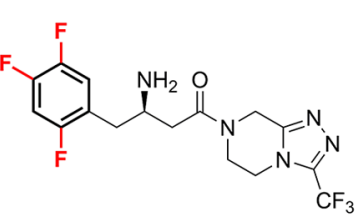

7

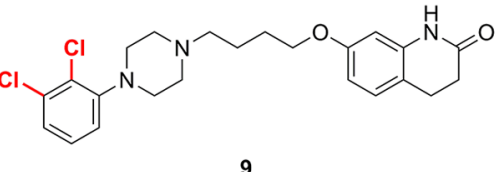

9

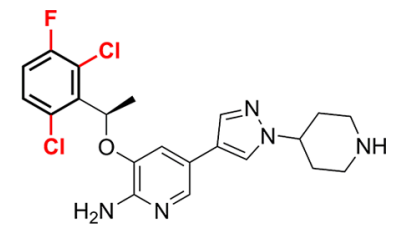

8

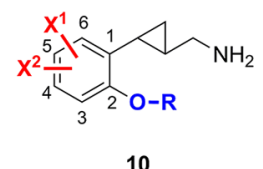

10
Figure 2. Representative drugs having a multihalogen substitution pattern and the general structure of new 2-phenylcyclopropylmethylamines.

Moreover, the role of halogen binding in protein-ligand interactions has been studied recently, ${ }^{31}$ and halogen bonds have been proposed to provide molecular interactions orthogonal to hydrogen bonds. ${ }^{32}$ The lipophilicity of halogen atoms, which enhances the LogP values of small molecules, might also improve the blood-brain barrier (BBB) permeability of compounds designed for CNS indications.

Encouraged by the promising results that had been achieved for the monohalogenated compounds, ${ }^{23}$ and the possible beneficial effect of a second halogen, we synthesized a new series of compounds containing two halogen substituents on the benzene ring, as depicted by the general structure 10 (Figure 2). The synthesis and SAR results are described herein, along with the ADMET evaluation and efficacy study of a key compound in four different schizophrenia-related animal behavioral models.

Chemical Synthesis and Pharmacological Profiling. The synthesis of the dihalogenated compounds was achieved employing methods similar to those reported by us previously, starting from the corresponding benzaldehydes. Thus, various dihalogenated benzaldehydes $11 \mathbf{a}-\mathbf{g}$ were purchased or prepared according to literature methods (for details, see Supporting Information). As shown in Scheme 1, the benzaldehydes 11a-g were converted to the corresponding acrylamides $12 \mathrm{a}-\mathrm{g}$, with the double bond in the $E$ configuration, using the commercially available Wittig reagent $N$-methoxy- $N$-methyl(triphenylphosphoranylidene)acetamide. This reagent was preferred over ethyl 2-(triphenylphosphoranylidene)acetate due to the facts that better or complete $E$ selectivity was observed for the newly formed double bond and that the subsequent cyclopropanation step proceeds more efficiently with $\alpha, \beta$-unsaturated Weinreb amides than with esters. ${ }^{33,34}$ The acrylamides $12 \mathbf{a}-\mathbf{g}$ were then subjected to the Corey-Chaykovsky cyclopropanation reaction to generate the cyclopropanes $13 \mathbf{a}-\mathbf{g}$ as their trans isomers, using the sulfur ylide generated from trimethylsulfoxonium iodide by treatment with sodium hydride. Next, sequential reduction using DIBAL-H followed by sodium borohydride provided alcohols $14 \mathbf{a}-\mathrm{g}$ in good yields. Mitsunobu reactions of 
Scheme 1. Synthesis of Target Compounds $20 \mathrm{a}-\mathrm{g}, 21 \mathrm{a}-\mathrm{g}$, and $22 \mathrm{a}-\mathrm{g}^{a}$<smiles>[X][X]c1ccc(OC)c(/C=C/C(=O)N(C)OC)c1</smiles><smiles>[Y4]c1ccc(OC)c(C2CC2CN2C(=O)c3ccccc3C2=O)c1</smiles>

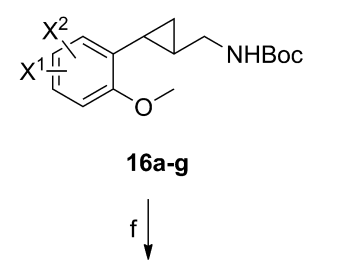
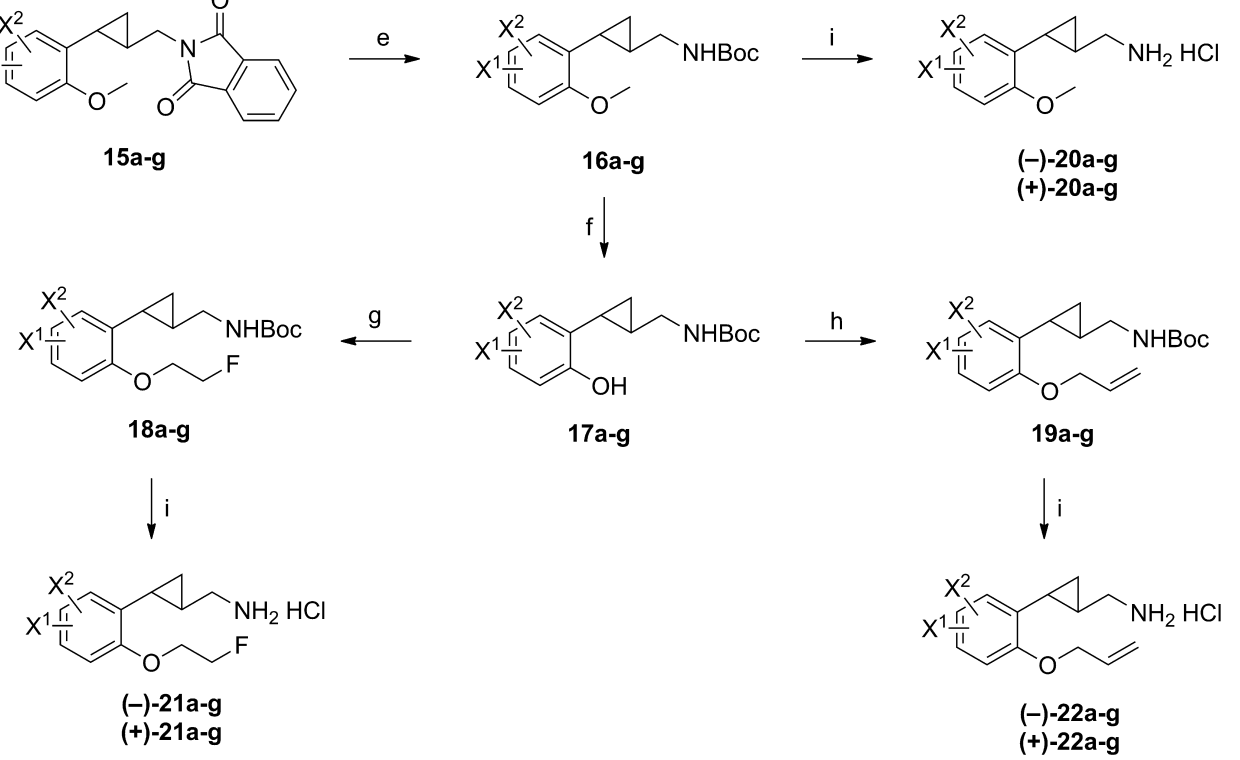

${ }^{a}$ Reagents and conditions: (a) $\mathrm{Ph}_{3} \mathrm{P}=\mathrm{CHC}(\mathrm{O}) \mathrm{N}(\mathrm{OMe}) \mathrm{Me}, \mathrm{CH}_{2} \mathrm{Cl}_{2}$, rt, overnight; (b) $\mathrm{Me}_{3} \mathrm{~S}^{+}(\mathrm{O}) \mathrm{I}^{-}, \mathrm{NaH}$, DMSO, rt, overnight; (c) DIBAL-H, THF, $-78{ }^{\circ} \mathrm{C}, 2 \mathrm{~h}$; then $\mathrm{NaBH}_{4}, \mathrm{MeOH}, 0{ }^{\circ} \mathrm{C}$ to rt, $0.5 \mathrm{~h}$; (d) phthalimide, $\mathrm{PPh}_{3}$, DEAD, THF, rt, overnight; (e) $\mathrm{N}_{2} \mathrm{H}_{4}-\mathrm{H}_{2} \mathrm{O}, \mathrm{EtOH}$, reflux, $3 \mathrm{~h}$; then $\mathrm{Boc}_{2} \mathrm{O}, \mathrm{Et}_{3} \mathrm{~N}, \mathrm{CH}_{2} \mathrm{Cl}_{2}$, rt, $0.5 \mathrm{~h}$; (f) $\mathrm{BBr}_{3}, \mathrm{CH}_{2} \mathrm{Cl}_{2},-78{ }^{\circ} \mathrm{C}$ to rt, $3 \mathrm{~h}$; then $\mathrm{Boc}_{2} \mathrm{O}, \mathrm{Et}_{3} \mathrm{~N}, \mathrm{CH}_{2} \mathrm{Cl}_{2}, \mathrm{rt}, 0.5 \mathrm{~h}$; (g) 2-fluoroethanol, $\mathrm{Ph}_{3} \mathrm{P}, \mathrm{DEAD}$, THF, 0 to $60{ }^{\circ} \mathrm{C}$ (microwave), $1 \mathrm{~h}$; (h) allyl bromide, $\mathrm{Cs}_{2} \mathrm{CO}_{3}$, DMF, $80{ }^{\circ} \mathrm{C}$ (microwave), $0.5-1 \mathrm{~h}$; (i) (1) chiral preparative-HPLC; (2) $2 \mathrm{M} \mathrm{HCl}$ in $\mathrm{Et}_{2} \mathrm{O}$, rt, 24-48 h. 11-22a: 4,5-diF; 11-22b: 5,6-diF; 11-22c: 4-F, 5-Cl; 11-22d: 5-Cl, 6-F; 11-22e: 4,5-diCl; 11-22f: 5,6-diCl; 11-22g: 5-F, 6-Cl.

$14 a-g$ with phthalimide produced the phthalimides $15 a-g$ in excellent yields. Deprotection of these imides with hydrazine hydrate afforded the primary amines, which were protected as their Boc intermediates $16 \mathbf{a}-\mathrm{g}$. Demethylation of intermediates $16 \mathrm{a}-\mathrm{g}$ with $\mathrm{BBr}_{3}$ in dichloromethane afforded the phenol intermediates $17 \mathbf{a}-\mathrm{g}$. In our previous SAR studies, ${ }^{23}$ the analogues containing 2-fluoroethyl and allyl ether moieties were found to provide compounds with the best pharmacological profiles. Thus, the phenols $17 \mathrm{a}-\mathrm{g}$ were converted to the 2-fluoroethyl ethers $18 \mathbf{a}-\mathbf{g}$ using Mitsunobu conditions while alkylation of $17 \mathbf{a}-\mathrm{g}$ with allyl bromide afforded allyl ethers $19 \mathrm{a}-\mathrm{g}$. The racemic compounds $16 a-g, 18 a-g$, and $19 a-g$ were then resolved by chiral preparative-HPLC to provide both the $(-)$ - and (+)-enantiomers, which were then deprotected with $\mathrm{HCl}$ in ether to afford both enantiomers of compounds $20 \mathrm{a}-\mathrm{g}, 21 \mathrm{a}-\mathrm{g}$, and $22 \mathbf{a}-\mathbf{g}$ as their $\mathrm{HCl}$ salts.

All compounds were screened in functional assays at the $5-\mathrm{HT}_{2 \mathrm{C}}, 5-\mathrm{HT}_{2 \mathrm{~B}}$, and $5-\mathrm{HT}_{2 \mathrm{~A}}$ receptors. Data were acquired using recombinant, stably expressed human $5-\mathrm{HT}_{2}$ receptors in the HEK-293 cell line, using a fluorescence imaging plate reader (FLIPR) assay as described previously. ${ }^{23}$

As shown in Table 1, a 2-methoxy substituent provides analogues with good potency but poor selectivity for $5-\mathrm{HT}_{2 \mathrm{C}}$, while the 2-fluoroethoxy and allyloxy substituents afford compounds with sometimes reduced but in other cases preserved $5-\mathrm{HT}_{2 \mathrm{C}}$ potency and improved selectivity.

Compared to compounds bearing a single fluorine or chlorine group at position $5,^{23}$ those with an additional fluorine atom at position 4 or 6 exhibited slightly modified pharmacological profiles. In comparison to the 5,6-difluorinated compounds, the 4,5-difluoro substitution pattern led to better potency, as shown by the pairs $(+)-20 a$ vs $(+)-20 b,(+)-21 a$ vs $(+)-21 \mathbf{b}$, and $(+)-22 \mathbf{a}$ vs $(+)-22 \mathbf{b}$, wherein an approximately 3 -fold difference can be observed within each pair. Importantly, the 2-fluoroethyl and allyl ethers provided improved subtype selectivity due to loss of potency at $5-\mathrm{HT}_{2 \mathrm{~A}}$ and $5-\mathrm{HT}_{2 \mathrm{~B}}$ receptors. Thus, compounds (+)-21a, (+)-22a, (+)-21b, and (+)-22b showed moderate to excellent profiles as selective $5-\mathrm{HT}_{2 \mathrm{C}}$ agonists. Notably, compound (+)-22a represents the best of this series, exhibiting an $\mathrm{EC}_{50}$ value of $8.7 \mathrm{nM}$ at the $5-\mathrm{HT}_{2 \mathrm{C}}$ receptors, with $>200$-fold selectivity over $5-\mathrm{HT}_{2 \mathrm{~B}}$ and $>50$-fold selectivity over $5-\mathrm{HT}_{2 \mathrm{~A}}$. Given the fact that this compound displayed very weak activation of both the $5-\mathrm{HT}_{2 \mathrm{~B}}$ receptors $\left(E_{\max }=35 \%\right)$ and $5-\mathrm{HT}_{2 \mathrm{~A}}$ receptors $\left(E_{\max }=21 \%\right),(+)-22 \mathrm{a}$ is a good candidate for further studies. Considering that the 5-monofluoro analogue of $(+)$-22a showed greater $5-\mathrm{HT}_{2 \mathrm{~A}}$ agonist efficacy, the superiority of compound (+)-22a over its 5-monofluoro analogue relies on its very weak $5-\mathrm{HT}_{2 \mathrm{~A}}$ activity, as the latter showed greater activation of the same receptor $\left(\mathrm{EC}_{50}=374 \mathrm{nM}, E_{\max }=56 \%\right){ }^{23}$

Similarly, the 4-fluoro-5-chloro-substituted analogues provided an advantage with respect to potency compared to the 5-chloro-6-fluoro scaffold, which is illustrated by comparisons of $(+)-20 \mathrm{c}$ vs $(+)-20 \mathrm{~d},(+)-21 \mathrm{c}$ vs $(+)-21 \mathrm{~d}$, and $(+)-22 \mathrm{c}$ vs $(+)-22 d$. Compound (+)-22c displayed an $\mathrm{EC}_{50}$ of $42 \mathrm{nM}$ at $5-\mathrm{HT}_{2 \mathrm{C}}$, no activity at $5-\mathrm{HT}_{2 \mathrm{~A}}$ and good selectivity over $5-\mathrm{HT}_{2 \mathrm{~B}}$ $\left(\mathrm{EC}_{50}=1001 \mathrm{nM}, \mathrm{E}_{\max }=34 \%\right)$. 
Table 1. Pharmacological Profiles of Dihalogenated Compounds at 5-HT Receptors $^{a}$

\begin{tabular}{|c|c|c|c|c|c|c|c|}
\hline \multirow{2}{*}{ Structure (HCI salt) } & \multirow{2}{*}{ Compound } & \multicolumn{2}{|c|}{$5-\mathrm{HT}_{2 \mathrm{C}}$} & \multicolumn{2}{|c|}{$5-\mathrm{HT}_{2 \mathrm{~B}}$} & \multicolumn{2}{|c|}{$5-\mathrm{HT}_{2 \mathrm{~A}}$} \\
\hline & & $\mathrm{pEC}_{50}\left(\mathrm{EC}_{50}, \mathrm{nM}\right)$ & $E_{\max }(\%)$ & $\mathrm{pEC}_{50}\left(\mathrm{EC}_{50}, \mathrm{nM}\right)$ & $E_{\max }(\%)$ & $\mathrm{pEC}_{50}\left(\mathrm{EC}_{50}, \mathrm{nM}\right)$ & $E_{\max }(\%)$ \\
\hline - & 5-HT & $9.66 \pm 0.04(0.18)$ & $100 \pm 1$ & $8.89 \pm 0.05(1.0)$ & $100 \pm 2$ & $8.87 \pm 0.03(1.9)$ & $100 \pm 1$ \\
\hline- & lorcaserin & $8.74 \pm 0.02(2.7)$ & $98 \pm 1$ & $6.29 \pm 0.05(328)$ & $80 \pm 3$ & $6.78 \pm 0.01(258)$ & $67 \pm 1$ \\
\hline & $(-)-20 a$ & $7.50 \pm 0.02(30)$ & $104 \pm 1$ & $6.40 \pm 0.03(400)$ & $59 \pm 1$ & $6.29 \pm 0.02(511)$ & $76 \pm 1$ \\
\hline & $(+)-20 a$ & $8.50 \pm 0.02$ & $108 \pm 1$ & $7.56 \pm 0.03(27)$ & $69 \pm 1$ & $7.09 \pm 0.02(81)$ & $81 \pm 1$ \\
\hline & $(-)-21 \mathbf{a}$ & $6.11 \pm 0.01(772)$ & $73 \pm 1$ & NA & NA & NA & NA \\
\hline & $(+)-21 \mathbf{a}$ & $8.14 \pm 0.02(7.3)$ & $95 \pm 1$ & $6.34 \pm 0.13(453)$ & $32 \pm 3$ & $6.44 \pm 0.02(361)$ & $51 \pm 1$ \\
\hline & $(-)-22 a$ & $6.94 \pm 0.02(116)$ & $94 \pm 1$ & NA & NA & $6.08 \pm 0.02(831)$ & $17 \pm 0$ \\
\hline & $(+)-22 \mathrm{a}$ & $8.06 \pm 0.02(8.7)$ & $97 \pm 1$ & $5.76 \pm 0.23(1745)$ & $35 \pm 7$ & $6.31 \pm 0.02(491)$ & $21 \pm 0$ \\
\hline & $(-)-20 b$ & $7.81 \pm 0.01(16)$ & $108 \pm 1$ & $6.34 \pm 0.03(462)$ & $62 \pm 1$ & $6.34 \pm 0.02(461)$ & $72 \pm 1$ \\
\hline & $(+)-20 b$ & $8.02 \pm 0.02(9.5)$ & $108 \pm 1$ & $6.68 \pm 0.03(209)$ & $64 \pm 1$ & $6.36 \pm 0.02(437)$ & $79 \pm 1$ \\
\hline & $(-)-21 b$ & $6.29 \pm 0.02(509)$ & $78 \pm 1$ & NA & NA & NA & NA \\
\hline & $(+)-21 b$ & $7.60 \pm 0.01(25)$ & $96 \pm 1$ & $5.66 \pm 0.09(2182)$ & $36 \pm 3$ & $5.63 \pm 0.01(2332)$ & $30 \pm 0$ \\
\hline & $(-)-22 b$ & $6.82 \pm 0.02(151)$ & $89 \pm 1$ & $5.35 \pm 0.18(4464)$ & $26 \pm 6$ & NA & NA \\
\hline & $(+)-22 b$ & $7.44 \pm 0.01(36)$ & $100 \pm 1$ & $5.48 \pm 0.11(3339)$ & $35 \pm 4$ & NA & NA \\
\hline & $(-)-20 c$ & $7.79 \pm 0.01(16)$ & $98 \pm 1$ & $6.48 \pm 0.04$ (329) & $44 \pm 1$ & $6.63 \pm 0.02$ & $88 \pm 1$ \\
\hline & $(+)-20 c$ & $8.11 \pm 0.02(7.6)$ & $97 \pm 1$ & $7.60 \pm 0.04(25)$ & $59 \pm 1$ & $7.09 \pm 0.04(81)$ & $93 \pm 2$ \\
\hline & $(-)-21 c$ & $6.11 \pm 0.01(776)$ & $70 \pm 1$ & $5.60 \pm 0.07(2521)$ & $26 \pm 2$ & NA & NA \\
\hline & $(+)-21 \mathrm{c}$ & $7.62 \pm 0.01(24)$ & $87 \pm 0$ & $6.30 \pm 0.10(506)$ & $39 \pm 2$ & $6.19 \pm 0.01(654)$ & $41 \pm 1$ \\
\hline & $(-)-22 c$ & $6.51 \pm 0.01(308)$ & $77 \pm 1$ & $5.71 \pm 0.11(1957)$ & $22 \pm 2$ & NA & NA \\
\hline & $(+)-22 \mathrm{c}$ & $7.38 \pm 0.01(42)$ & $87 \pm 1$ & $6.00 \pm 0.13(1001)$ & $34 \pm 0$ & NA & NA \\
\hline & $(-)-20 d$ & $8.42 \pm 0.04(3.8)$ & $93 \pm 1$ & $6.33 \pm 0.22(165)$ & $64 \pm 1$ & $7.17 \pm 0.02(68)$ & $86 \pm 1$ \\
\hline & $(+)-20 d$ & $7.88 \pm 0.03(13)$ & $92 \pm 1$ & $6.45 \pm 0.11$ & $52 \pm 6$ & $6.67 \pm 0.02(212)$ & $85 \pm 1$ \\
\hline & $(-)-21 d$ & $6.41 \pm 0.02(386)$ & $80 \pm 1$ & NA & NA & NA & NA \\
\hline & $(+)-21 d$ & $7.15 \pm 0.02(71)$ & $86 \pm 1$ & NA & NA & $6.03 \pm 0.01(934)$ & $40 \pm 0$ \\
\hline & $(-)-22 d$ & $6.78 \pm 0.02(165)$ & $87 \pm 1$ & NA & NA & $5.97 \pm 0.01(1081)$ & $16 \pm 0$ \\
\hline & $(+)-22 d$ & $6.94 \pm 0.02(116)$ & $90 \pm 1$ & NA & NA & NA & NA \\
\hline & $(-)-20 e$ & $7.87 \pm 0.04(14)$ & $89 \pm 2$ & NA & NA & $7.07 \pm 0.02(84)$ & $75 \pm 0$ \\
\hline & $(+)-20 \mathrm{e}$ & $8.01 \pm 0.04(9.7)$ & $95 \pm 2$ & $7.51 \pm 0.07$ & $45 \pm 2$ & $7.68 \pm 0.04(21)$ & $85 \pm 1$ \\
\hline & $(-)-21 \mathrm{e}$ & $6.36 \pm 0.01(435)$ & $75 \pm 0$ & NA & NA & NA & NA \\
\hline & $(+)-21 e$ & $7.74 \pm 0.02(18)$ & $87 \pm 1$ & NA & NA & $7.03 \pm 0.02(92)$ & $58 \pm 1$ \\
\hline & $(-)-22 e$ & $6.56 \pm 0.01(278)$ & $84 \pm 1$ & NA & NA & NA & NA \\
\hline & $(+)-22 \mathrm{e}$ & $7.21 \pm 0.01(61)$ & $88 \pm 1$ & $6.14 \pm 0.16(714)$ & $26 \pm 6$ & $6.78 \pm 0.02(167)$ & $37 \pm 0$ \\
\hline & $(-)-20 f$ & $8.96 \pm 0.03(0.95)$ & $104 \pm 1$ & $7.52 \pm 0.08(30)$ & $53 \pm 3$ & $7.75 \pm 0.03(38)$ & $88 \pm 1$ \\
\hline & $(+)-20 f$ & $7.78 \pm 0.02(21)$ & $98 \pm 1$ & $6.22 \pm 0.37(605)$ & $26 \pm 1$ & $6.82 \pm 0.02$ & $78 \pm 1$ \\
\hline & $(-)-21 \mathbf{f}$ & $6.65 \pm 0.01(224)$ & $85 \pm 1$ & NA & NA & NA & NA \\
\hline & $(+)-21 f$ & $6.63 \pm 0.01(232)$ & $90 \pm 1$ & NA & NA & $6.02 \pm 0.01(949)$ & $22 \pm 0$ \\
\hline & $(-)-22 f$ & $6.97 \pm 0.02(108)$ & $93 \pm 1$ & NA & NA & $6.37 \pm 0.02(426)$ & $32 \pm 1$ \\
\hline & $(+)-22 f$ & $6.78 \pm 0.01(165)$ & $70 \pm 0$ & NA & NA & NA & NA \\
\hline & $(-)-20 g$ & $8.50 \pm 0.02(3.2)$ & $96 \pm 1$ & $6.99 \pm 0.06(101)$ & $91 \pm 3$ & $6.92 \pm 0.01(119)$ & $72 \pm 1$ \\
\hline & $(+)-20 g$ & $7.62 \pm 0.45(24)$ & $89 \pm 2$ & NA & NA & $6.11 \pm 0.08(769)$ & $77 \pm 5$ \\
\hline & $(-)-21 g$ & $6.87 \pm 0.01(135)$ & $80 \pm 1$ & NA & NA & NA & NA \\
\hline & $(+)-21 g$ & $7.31 \pm 0.01(49)$ & $86 \pm 1$ & $6.02 \pm 0.09(961)$ & $55 \pm 5$ & $6.10 \pm 0.01(798)$ & $39 \pm 0$ \\
\hline & $(-)-22 g$ & $6.98 \pm 0.02(104)$ & $89 \pm 1$ & NA & NA & NA & NA \\
\hline & $(+)-22 g$ & $7.01 \pm 0.02(96)$ & $92 \pm 1$ & $6.03 \pm 0.08(927)$ & $55 \pm 4$ & NA & NA \\
\hline
\end{tabular}

${ }^{a}$ Data were acquired with recombinant, stably expressed human 5- $\mathrm{HT}_{2}$ receptors in the HEK-293 cell line, using a fluorescence imaging plate reader (FLIPR) assay; $\mathrm{pEC}_{50}$ and $E_{\max }$ values are shown as mean $\pm \mathrm{SEM}(n \geq 2)$; $\mathrm{EC}_{50} \mathrm{~s}$ are calculated from mean pEC $\mathrm{p}_{50}$ values; "NA", no activity $\left(E_{\max }<15 \%\right)$ at $10 \mu \mathrm{M}$.

The introduction of a second chlorine atom which is significantly larger than fluorine, into the 5-monochloro compound, led to a notable change in potency and selectivity. Compound (-)-20e, bearing a 4,5-dichloro substitution pattern, showed midnanomolar potency at the $5-\mathrm{HT}_{2 \mathrm{C}}$ receptor $\left(\mathrm{EC}_{50}=14 \mathrm{nM}\right)$ and no activity at $5-\mathrm{HT}_{2 \mathrm{~B}}$ but only moderate selectivity over
5- $\mathrm{HT}_{2 \mathrm{~A}}\left(\mathrm{EC}_{50}=84 \mathrm{nM}\right)$. Compound (+)-21e, with a 2-fluoroethoxy group at position 2, displayed an $\mathrm{EC}_{50}$ of $18 \mathrm{nM}$ and excellent selectivity against $5-\mathrm{HT}_{2 \mathrm{~B}}$ but only moderate selectivity against $5-\mathrm{HT}_{2 \mathrm{~A}}$.

Most of the compounds above displayed the same enantiomer preference as we had described previously, ${ }^{23}$ with the 
(+)-enantiomer showing greater potency. However, the introduction of a chlorine atom at position 6 , as in the compound 20f, led to the reversal of this preference. (-)-20f showed excellent $5-\mathrm{HT}_{2 \mathrm{C}}$ potency $\left(\mathrm{EC}_{50}=0.95 \mathrm{nM}\right), 31$-fold selectivity over $5-\mathrm{HT}_{2 \mathrm{~B}}$, and 40 -fold selectivity over $5-\mathrm{HT}_{2 \mathrm{~A}}$, while its enantiomer (+)-20f was 22-fold weaker $\left(\mathrm{EC}_{50}=21 \mathrm{nM}\right)$ at the $5-\mathrm{HT}_{2 \mathrm{C}}$ receptor. The introduction of a slightly larger 2-alkoxy group led to a decrease in potency, as shown by compounds $21 \mathrm{f}$ and 22f. With the combination of a 5-fluoro and 6-chloro group, similar enantiomer preference was observed for compound $20 \mathrm{~g}$, with the $(-)$-enantiomer showing higher potency $\left(\mathrm{EC}_{50}=\right.$ $3.2 \mathrm{nM})$. Although $(+)-20 \mathrm{~g}$ is 7.5 -fold weaker $\left(\mathrm{EC}_{50}=24 \mathrm{nM}\right)$ compared to $(-)-\mathbf{2 0 g}$, it showed better selectivity against $5-\mathrm{HT}_{2 \mathrm{~B}}$ (no activity) and 5- $\mathrm{HT}_{2 \mathrm{~A}}\left(\mathrm{EC}_{50}=769 \mathrm{nM}, 32\right.$-fold). Compounds $(-)-21 g$ and $(-)-22 g$ showed only midnanomolar potency at $5-\mathrm{HT}_{2 \mathrm{C}}$ but good selectivity against both $5-\mathrm{HT}_{2 \mathrm{~A}}$ and $5-\mathrm{HT}_{2 \mathrm{~B}}$ receptors (Table 1). In earlier work, based on the support of good internal consistency of our potency data, we tacitly assumed that enantiomers with the same sign of optical rotation as their parents devoid of substituents on the benzene ring had the same absolute configuration as those parents. ${ }^{26}$ An independent determination of the any of the new compounds' absolute configuration has not yet been carried out, but the observed switch of the eutomer from the (+)- to the (-)-isomer in the two compounds mentioned above may as well result from the sign of optical rotation for a given absolute configuration having changed in response to the change in the substitution pattern, as from the eutomer possessing the opposite absolute configuration in those cases.

The SAR results of the above dihalogenated ligands further demonstrate the strict steric limitations that apply to these 2-phenylcyclopropylmethylamine-based $5-\mathrm{HT}_{2 \mathrm{C}}$ ligands. As an example of these steric limitations, one can consider (-)-20f and the effect of increasing the size of its ether group from methoxy to allyloxy as in compound (-)-22f. This modification leads to a $\sim 100$-fold decrease in potency (108 $\mathrm{nM}$ vs $0.95 \mathrm{nM})$. Also, a $\sim 200$-fold loss in potency was observed for the 2-fluoroethoxycontaining compound (-)-21f (224 nM vs $0.95 \mathrm{nM})$. In fact, a decrease of greater than 2 -fold in potency was observed across all of the dihalogen-substituted compounds when the 2-alkoxy group was changed from methoxy to allyloxy or 2-fluoroethoxy. However, this loss in potency was accompanied by an improvement in selectivity in most cases.

$(+)-22 \mathrm{a}$ is the best compound in this series with respect to its $5-\mathrm{HT}_{2 \mathrm{C}}$ potency and selectivity against the $5-\mathrm{HT}_{2 \mathrm{~B}}(>200-$ fold $)$ and $5-\mathrm{HT}_{2 \mathrm{~A}}$ receptors (>50-fold). It was 3 -fold weaker than lorcaserin $\left(\mathrm{EC}_{50}=2.7 \mathrm{nM}\right)$ at $5-\mathrm{HT}_{2 \mathrm{C}}$ receptors in our assay, but lorcaserin showed much greater activation of both $5-\mathrm{HT}_{2 \mathrm{~B}}$ $\left(\mathrm{EC}_{50}=328 \mathrm{nM}, E_{\max }=80 \%\right)$ and $5-\mathrm{HT}_{2 \mathrm{~A}}$ receptors $\left(\mathrm{EC}_{50}=\right.$ $\left.258 \mathrm{nM}, E_{\max }=67 \%\right)$. The low $E_{\max }$ values of compound (+)-22a at both $5-\mathrm{HT}_{2 \mathrm{~B}}$ and $5-\mathrm{HT}_{2 \mathrm{~A}}$ receptors make it unlikely to cause side-effects associated with the activation of those receptors. To determine its off-target activity, compound (+)-22a was screened against a panel of 46 targets including serotonin receptors, dopamine receptors, adrenergic receptors, monoamine transporters, and other common CNS targets (see Supporting Information Table S1). ${ }^{35}$ Among these, 17 targets showed greater than 50\% binding at $10 \mu \mathrm{M}$; thus, $K_{\mathrm{i}}$ values were determined. As shown in Table 2, compound (+)-22a binds to $5-\mathrm{HT}_{2 \mathrm{C}}$ receptors with a $K_{\mathrm{i}}$ value of $29 \mathrm{nM}$, while exhibiting excellent selectivity over most other targets. Notably, compound (+)-22a binds to 5- $\mathrm{HT}_{2 \mathrm{~B}}$ with a $K_{\mathrm{i}}=68 \mathrm{nM}$, which indicates that the selectivity reported above is "functional", namely the compound binds to this receptor but
Table 2. Binding Affinity of Compound (+)-22a at Selected Targets $^{a}$

$\begin{array}{lcr}\text { target } & \mathrm{p} K_{\mathrm{i}} & K_{\mathrm{i}}(\mathrm{nM}) \\ 5-\mathrm{HT}_{1 \mathrm{~A}} & 6.03 \pm 0.14 & 750 \\ 5-\mathrm{HT}_{2 \mathrm{~A}} & 5.80 \pm 0.16 & 1573 \\ 5-\mathrm{HT}_{2 \mathrm{~B}} & 7.16 \pm 0.12 & 68 \\ 5-\mathrm{HT}_{2 \mathrm{C}} & 7.57 \pm 0.05 & 29 \\ 5-\mathrm{HT}_{6} & 6.94 \pm 0.08 & 111 \\ 5-\mathrm{HT}_{7} & 5.99 \pm 0.09 & 1274 \\ \mathrm{SERT} & 5.90 \pm 0.10 & 1259 \\ \mathrm{D}_{2} & 5.31 \pm 0.11 & 4898 \\ \mathrm{D}_{3} & 6.71 \pm 0.06 & 201 \\ \mathrm{D}_{4} & 5.77 \pm 0.17 & 1685 \\ \alpha_{2 \mathrm{~A}} & 6.78 \pm 0.31 & 661 \\ \alpha_{2 \mathrm{~B}} & 6.42 \pm 0.14 & 1549 \\ \alpha_{2 \mathrm{C}} & 6.56 \pm 0.19 & 278 \\ \beta_{2} & 6.09 \pm 0.04 & 807 \\ \mathrm{H}_{2} & 5.47 \pm 0.22 & 3388 \\ \mathrm{M}_{5} & 5.55 \pm 0.07 & 2840 \\ \sigma_{2} & 5.68 \pm 0.25 & 2113\end{array}$

${ }^{a}$ Binding profiles were tested by the National Institute of Mental Health's Psychoactive Drug Screening Program (NIMH PDSP). Each value of $\mathrm{p} K_{\mathrm{i}}$ is shown as mean $\pm \operatorname{SEM}(n=2-5) ; K_{\mathrm{i}}$ presents the value calculated from mean $\mathrm{p} K_{\mathrm{i}}$.

its intrinsic activity is very low $\left(\mathrm{EC}_{50}=1745 \mathrm{nM}, E_{\max }=35 \%\right)$. Interestingly, compound (+)-22a also binds to the 5- $\mathrm{HT}_{6}$ receptor with a low $K_{\mathrm{i}}$ value $(111 \mathrm{nM})$. Because both $5-\mathrm{HT}_{6}$ agonists and antagonists have been shown to represent potential therapeutics for treating cognitive deficits such as those observed in Alzheimer's disease (AD), ${ }^{36,37}$ the affinity of $(+)-22 a$ for this receptor may be a desirable feature rather than represent an undesirable side effect. We thus selected $(+)-22 a$ for further studies of its ADMET properties and in vivo efficacy in animal behavioral models.

ADMET Study of Compound (+)-22a. The liver microsomal stability of (+)-22a using both human and mouse microsomes was assayed, and the data are shown in Table 3.

Table 3. Liver Microsomal Stability of Compound (+)-22a ${ }^{a}$

\begin{tabular}{|c|c|c|c|c|c|c|}
\hline \multirow[b]{3}{*}{ assay format } & \multicolumn{6}{|c|}{ remaining percentage (\%) } \\
\hline & \multicolumn{3}{|c|}{ HLM } & \multicolumn{3}{|c|}{ MLM } \\
\hline & $0 \mathrm{~min}$ & $30 \mathrm{~min}$ & $120 \mathrm{~min}$ & $0 \mathrm{~min}$ & $30 \mathrm{~min}$ & $120 \mathrm{~min}$ \\
\hline$+\mathrm{NADPH}$ & 100.0 & 91.9 & 70.5 & 100.0 & 68.1 & 32.4 \\
\hline - NADPH & 100.0 & 94.7 & 81.9 & 100.0 & 97.8 & 79.6 \\
\hline
\end{tabular}

${ }^{a}$ Concentration of liver microsomes was $0.5 \mathrm{mg} / \mathrm{mL}$ and $(+)-22 \mathrm{a}$ was tested at a concentration of $2 \mu \mathrm{M}$; HLM $=$ human liver microsomes; $\mathrm{MLM}=$ mouse liver microsomes.

Better stability was observed in the mouse liver microsomes in the absence of NADPH, indicating that oxidative mechanisms are likely involved in the metabolism of this compound. In the presence of NADPH, only $32.4 \%$ of (+)-22a remained after $2 \mathrm{~h}$. In contrast, the compound's stability in the presence of human liver microsomes is much better, with $70.5 \%$ of the parent compound remaining under the same conditions. Thus, good metabolic stability is anticipated in humans.

A frequently confronted challenge in developing CNStargeted drugs is insufficient blood-brain barrier (BBB) penetration. Thus, compound (+)-22a was tested in mice to verify its CNS exposure. The compound was administered intraperitoneally 
Table 4. Brain Penetration Study of Compound (+)-22a

\begin{tabular}{|c|c|c|c|c|c|c|}
\hline route & $\underset{(\mathrm{h})}{\text { time }}$ & $\begin{array}{c}\text { animal } \\
\text { ID }\end{array}$ & $\begin{array}{l}\text { brain } \\
(\mathrm{ng} / \mathrm{g})\end{array}$ & $\begin{array}{c}\text { plasma } \\
(\mathrm{ng} / \mathrm{mL})\end{array}$ & $\begin{array}{l}\text { ratio (brain/ } \\
\text { plasma) }^{a}\end{array}$ & mean \\
\hline \multirow[t]{4}{*}{ ip $10 \mathrm{mg} / \mathrm{kg}$} & 0.5 & 1 & 10120 & 321 & 31.5 & 29.9 \\
\hline & & 2 & 8480 & 300 & 28.3 & \\
\hline & 2.0 & 1 & 3948 & 96.4 & 41.0 & 45.0 \\
\hline & & 2 & 2228 & 45.4 & 49.1 & \\
\hline
\end{tabular}

${ }^{a}$ Density of brain tissue is calculated as $1.0 \mathrm{~g} / \mathrm{mL}$.

(ip) to CD1 mice at a dose of $10 \mathrm{mg} / \mathrm{kg}$, and both brain and plasma concentrations were assayed at the 0.5 and $2 \mathrm{~h}$ time-points (Table 4). Excellent brain penetration was observed for compound (+)-22a, with brain/plasma concentration ratios of 29.9 and 45.0 at 0.5 and $2.0 \mathrm{~h}$, respectively. The high brain penetrance of this compound should thus maximize its exposure in the CNS, allowing for robust activation of central $5-\mathrm{HT}_{2 \mathrm{C}}$ receptors, while at the same time minimizing possible side effects due to compound interactions with peripheral systems.

The inhibition of the cytochrome P450 enzymes by (+)-22a was tested at five different isoforms, and the data are shown in Table 5. Although a high inhibition of CYP 1A2 (86\%) was

Table 5. Cytochrome P450 Inhibition by Compound $(+)-22 a^{a}$

$\begin{array}{lc}\text { CYP isoform (substrate) } & \text { inhibition (\%) } \pm \text { SEM } \\ \text { 1A2 (phenacetin) } & 86.0 \pm 0.25 \\ \text { 2C9 (tolbutamide) } & 29.2 \pm 2.2 \\ \text { 2C19 (mephenytoin) } & 32.0 \pm 5.3 \\ \text { 2D6 (dextromethorphan) } & 43.5 \pm 3.0 \\ \text { 3A4 (midazolam) } & 3.4 \pm 1.6\end{array}$

${ }^{a}$ Compound (+)-20a was tested at $10 \mu \mathrm{M}(n=2)$; concentration of human liver microsomes was $0.2 \mathrm{mg} / \mathrm{mL}$; concentrations of phenacetin, tolbutamide, mephenytoin, dextromethorphan, and midazolam were $40,200,50,10$, and $5 \mu \mathrm{M}$, respectively.

observed with (+)-22a when it was tested at a concentration of $10 \mu \mathrm{M}$, low inhibition was observed for the other, more abundant isoforms, especially CYP 3A4 (3.4\% inhibition at $10 \mu \mathrm{M})$. Furthermore, inhibition of the human Ether-à-go-go related gene (hERG) channel was also tested, and (+)-22a displayed a dosedependent inhibition of hERG, with an $\mathrm{IC}_{50}$ value of $9.1 \mu \mathrm{M}$. This was not unexpected, as the structure of $(+)-22$ a falls into the common templates which are known to cause hERG inhibition. ${ }^{38}$ However, the high brain/plasma concentration ratios found for this compound should minimize the possible cardiac toxicity associated with hERG inhibition.

Efficacy Study of Compound (+)-22a in Animal Models of Schizophrenia-Like Behaviors. To explore the possible use of (+)-22a in the treatment of schizophrenia, this compound was tested in four different animal behavioral paradigms. The open field test was used to evaluate the ability of the compound to decrease hyperlocomotion using $d$-amphetamine $(\mathrm{AMPH})$ as the stimulant, whereas the AMPH-disrupted prepulse inhibition (PPI) test was used to analyze possible compound effects on abnormalities in sensorimotor gating. ${ }^{39,40}$ The well-known novel object recognition memory (NORM) test using transgenic $\mathrm{N}$-methyl-D-aspartate (NMDA) receptor NR1-knockdown (KD) mice was conducted to assess the ability of the compound to improve cognition. ${ }^{41}$ Lastly, the ability of (+)-22a to induce catalepsy was evaluated and compared to haloperidol. These data are detailed below.
Open Field Activity. The baseline activity of the mice was assessed for $15 \mathrm{~min}$ before the administration of AMPH ( $3 \mathrm{mg} / \mathrm{kg}$, ip). During this period, only those mice from the $30 \mathrm{mg} / \mathrm{kg}(+)-22 \mathrm{a}+\mathrm{AMPH}$ group showed a small, albeit significant $(p<0.040)$, reduction in locomotion compared to the Veh + AMPH group; all other groups had similar levels of baseline activities (Figure 3A,B). Administration of AMPH induced a significant increase in locomotor activity, as shown by the comparison of the Veh + AMPH group with the Veh + Veh group (Figure 3A,C). Animals given (+)-22a showed a dose-dependent suppression of AMPH-stimulated hyperlocomotion; the $2 \mathrm{mg} / \mathrm{kg}$ dose showed no significant efficacy while $5,10,20$, and $30 \mathrm{mg} / \mathrm{kg}$ significantly reduced the hyperactivity compared to the Veh + AMPH group. Notably, locomotor activities of mice treated with 20 or $30 \mathrm{mg} / \mathrm{kg}(+)-22 \mathrm{a}+\mathrm{AMPH}$ did not significantly differ from animals in the $20 \mathrm{mg} / \mathrm{kg}(+)-22 a+$ Veh or the Veh + Veh control groups which had similar activity levels. Thus, a dose of 20 or $30 \mathrm{mg} / \mathrm{kg}$ of (+)-22a reduced the animals' activities to normal levels.

Prepulse Inhibition (PPI). The Veh + AMPH group showed a marked suppression of PPI compared to Veh + Veh controls $(p<0.007)$ and a loss of prepulse dependency at the 8 and $12 \mathrm{~dB}$ prepulse intensities (Figure 4A). The suppression was reversed by both $0.5(p<0.01)$ and $1 \mathrm{mg} / \mathrm{kg}(p<0.05)$ doses of $(+)-22 \mathrm{a}$, and the PPI was restored in both groups. Mice treated with the $1 \mathrm{mg} / \mathrm{kg}$ dose $+\mathrm{AMPH}$ showed full prepulse dependency of the PPI response, with the percentages of the PPI at 4,8 , and $12 \mathrm{~dB}$ being significantly distinguished from each other $(p<0.010)$. Although $2 \mathrm{mg} / \mathrm{kg}(+)-22 \mathrm{a}$ increased AMPH-disrupted PPI, this effect was not significantly different from the Veh $+\mathrm{AMPH}$ group. Mice in the $4 \mathrm{mg} / \mathrm{kg}(+)-22 a+$ Veh group exhibited PPI levels which were indistinguishable from the Veh + Veh group. However, the $4 \mathrm{mg} / \mathrm{kg}$ dose failed to increase AMPH-disrupted PPI.

The startle or "pulse-only" responses to the $120 \mathrm{~dB}$ acoustic stimulus (Figure 4B) were similar among the Veh + Veh, $4 \mathrm{mg} /$ $\mathrm{kg}(+)-22 \mathrm{a}+\mathrm{Veh}, \mathrm{Veh}+\mathrm{AMPH}$, and $4 \mathrm{mg} / \mathrm{kg}(+)-22 \mathrm{a}+\mathrm{AMPH}$ groups. In contrast, the $0.5,1$, and $2 \mathrm{mg} / \mathrm{kg}$ doses of this compound decreased startle activities, with the $0.5 \mathrm{mg} / \mathrm{kg}$ dose significantly reducing this response relative to the Veh + Veh, $4 \mathrm{mg} / \mathrm{kg}(+)-22 \mathrm{a}+\mathrm{Veh}, \mathrm{Veh}+\mathrm{AMPH}$, and $4 \mathrm{mg} / \mathrm{kg}(+)-\mathbf{2 2 a}+$ AMPH groups $(p s<0.035)$. Null activities were not distinguished across treatment conditions, with activities averaging $10.60 \pm 0.53 \mathrm{AU}$ across all animals, which accounted for less than $4 \%$ of the average pulse-only response. Together, these data demonstrate that (+)-22a can normalize AMPH-disrupted PPI and restore the prepulse dependency of the response, with $1 \mathrm{mg} / \mathrm{kg}$ showing the best efficacy.

Novel Object Recognition Memory (NORM). This task in rodents is considered similar to testing declarative memory in humans, and individuals with schizophrenia are deficient on declarative memory tasks. ${ }^{42,43}$ We used the transgenic NR1-KD mice since these mice represent a hypoglutamatergic model of schizophrenia and are deficient on the NORM test. ${ }^{41,40}$

As expected, vehicle-treated wild-type (WT) mice displayed a preference for the novel object at testing, whereas the NR1-KD animals showed no preference for either object $(p<0.001$; Figure 5A). Administration of $1 \mathrm{mg} / \mathrm{kg}(+)-22 \mathrm{a}$ attenuated NORM in WT animals $(p<0.010)$. By comparison, the 0.5 and $1 \mathrm{mg} / \mathrm{kg}$ doses increased novel object preference in NR1-KD mice, and $1 \mathrm{mg} / \mathrm{kg}(+)-22 \mathrm{a}$ significantly enhanced this preference relative to the vehicle-treated NR1-KD animals $(p<0.002)$ to a level that was indistinguishable from the WT vehicle control. 

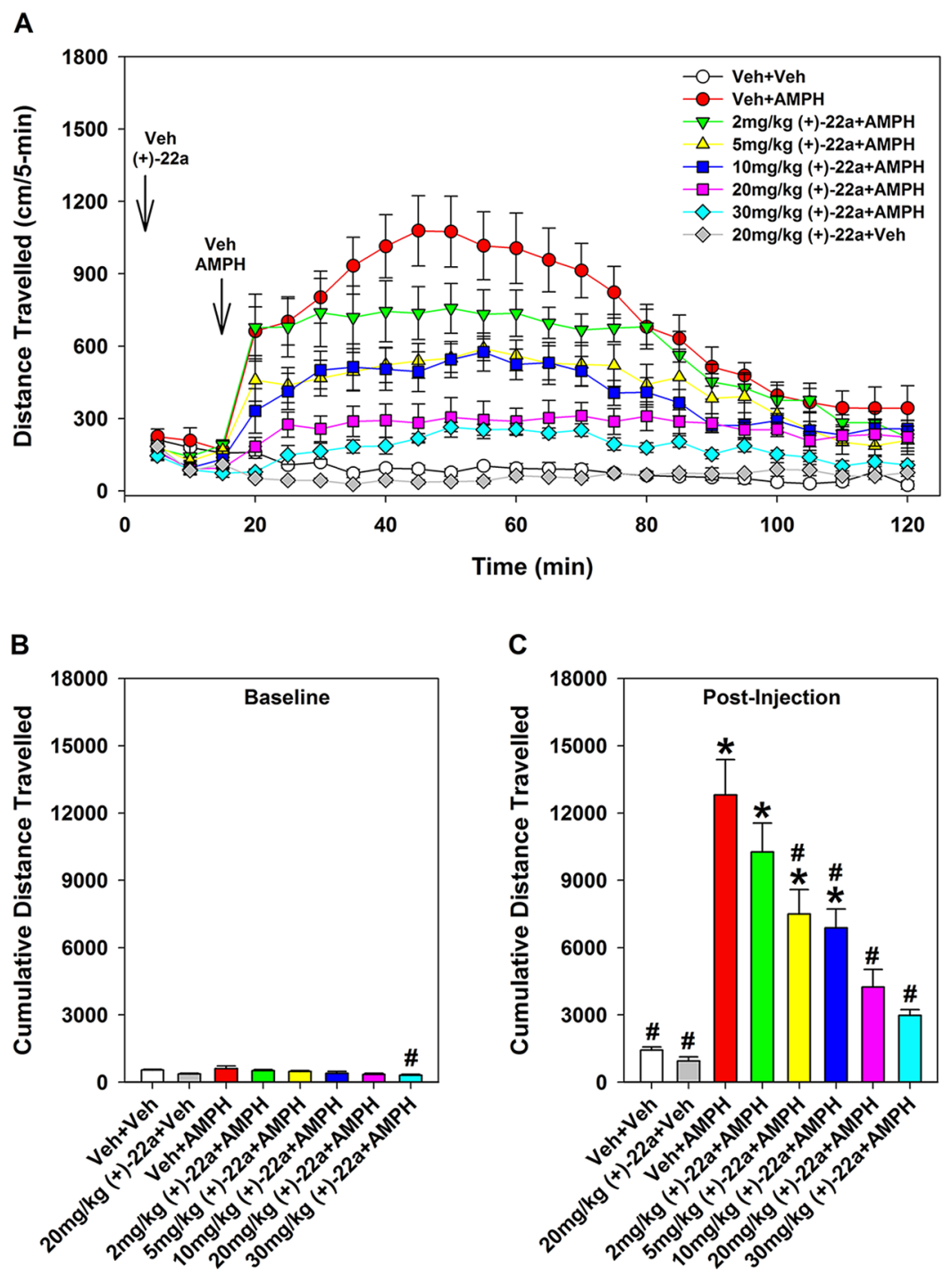

Figure 3. Effects of compound (+)-22a on $d$-amphetamine (AMPH)-stimulated hyperlocomotion in the open field. (A) Locomotor activity in the open field in $5 \mathrm{~min}$ blocks reflecting baseline responses (0-15 $\mathrm{min})$ and AMPH-stimulated activity with its reduction by $(+)-22 \mathrm{a}(15-120 \mathrm{~min})$. (B) Cumulative baseline locomotor activities (0-15 min). (C) Cumulative AMPH-stimulated activities and reductions in activity with $(+)$-22a (15-90 min). $N=7-10$ mice/treatment; $*, p<0.05$, compared to the Veh + Veh group; \#, $p<0.05$, compared to the Veh + AMPH group.

Hence, the $1 \mathrm{mg} / \mathrm{kg}$ dose decreased NORM in WT mice, but augmented it in the hypoglutamatergic NR1-KD animals.

To determine whether the differences in responses between the genotypes or among the doses of $(+)-22$ a could be attributed to neophobia, total object exploration times were examined both at training and at testing for long-term memory (LTM). The vehicle-treated NR1-KD mice were observed to spend more time exploring objects than WT controls at both training $(p<0.006$; Figure 5B) and testing $(p<0.032$; Figure 5C). By contrast, following administration of 0.5 or $1 \mathrm{mg} / \mathrm{kg}(+)-22 \mathrm{a}$, object exploration was similar between genotypes during training and testing. Hence, the rescue of NORM in NR1-KD mice cannot be attributed to neophobia in these mutants.

Catalepsy. We next determined whether compound (+)-22a had any cataleptic activity as compared with the vehicle and haloperidol responses. Catalepsy at baseline prior to injection (time 0 ) was similar for all groups with time in catalepsy $\leq 1 \mathrm{~s}$ (data not shown). One hour after injection, catalepsy was very low in all groups given 0.01 to $30 \mathrm{mg} / \mathrm{kg}(+)-22 \mathrm{a}$ and this result was not significantly different from that of the vehicle control
(Figure 6). In contrast, catalepsy was observed to increase in a dose-dependent fashion with haloperidol, such that responses at the 1 and $10 \mathrm{mg} / \mathrm{kg}$ doses were significantly higher than those for all groups given (+)-22a as well as that for the vehicle control $(p s<0.001)$. These findings demonstrate that the cataleptic potential of $(+)-22 \mathrm{a}$ is extremely low.

\section{CONCLUSION}

A new series of cyclopropylmethylamine-based $5-\mathrm{HT}_{2 \mathrm{C}}$ ligands bearing two halogen substituents on the phenyl ring have been designed and synthesized to further optimize this class of molecules. Compound (+)-22a was identified as a potent 5- $\mathrm{HT}_{2 \mathrm{C}}$ receptor agonist $\left(\mathrm{EC}_{50}=8.7 \mathrm{nM}, E_{\max }=97 \%\right)$, with good selectivity against the $5-\mathrm{HT}_{2 \mathrm{~B}}\left(\mathrm{EC}_{50}=1745 \mathrm{nM}, E_{\max }=35 \%\right)$ and $5-\mathrm{HT}_{2 \mathrm{~A}}$ receptors $\left(\mathrm{EC}_{50}=491 \mathrm{nM}, \mathrm{E}_{\max }=21 \%\right)$. Improved selectivity over the 5- $\mathrm{HT}_{2 \mathrm{~A}}$ receptor has been achieved in comparison to the analogue containing a single fluorine substituent, which showed moderate potency at the $5-\mathrm{HT}_{2 \mathrm{~A}}$ receptor as well as higher efficacy $\left(\mathrm{EC}_{50}=374 \mathrm{nM}, E_{\max }=56 \%\right) .{ }^{23}$ In ADMET tests, compound (+)-22a displayed good stability in the liver micro- 
A

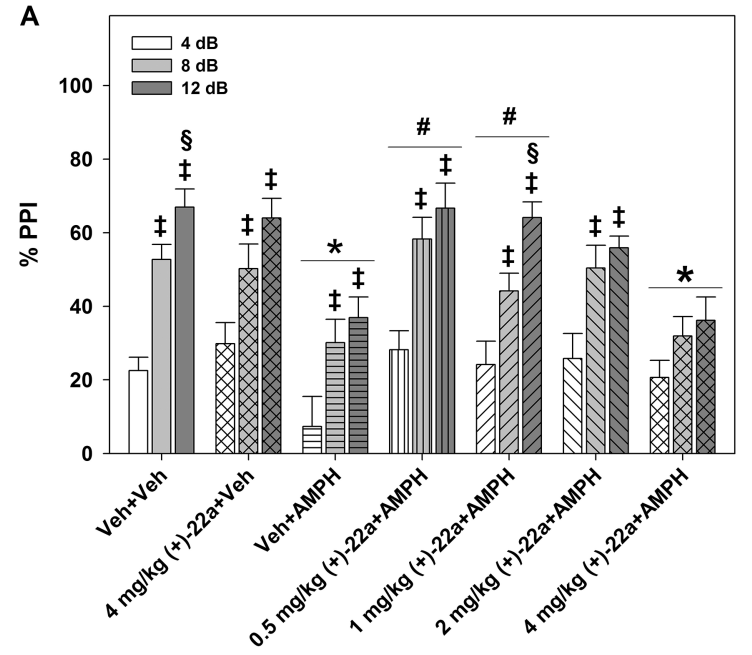

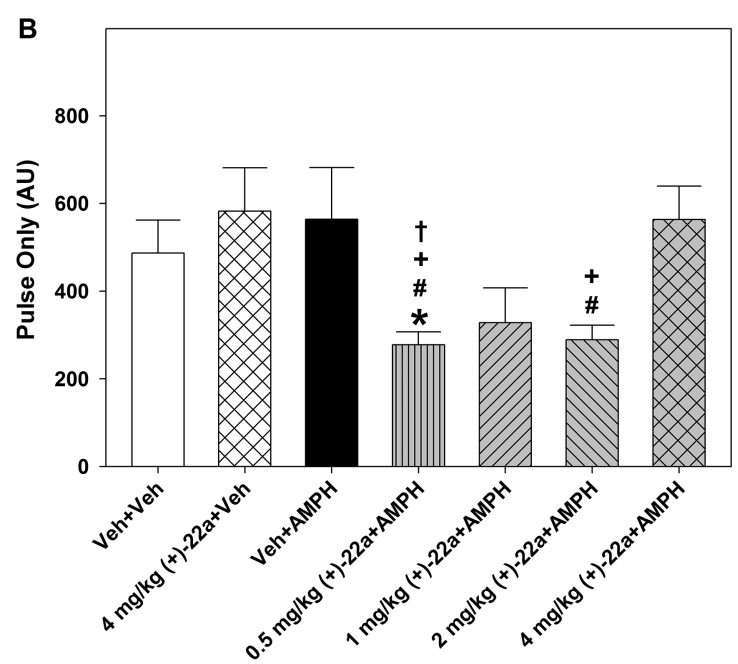

Figure 4. Compound (+)-22a restores $d$-amphetamine (AMPH)-disrupted PPI in C57BL/6J mice. (A) Mice treated with vehicle-vehicle (Veh + Veh) showed prepulse dependency in PPI. Four mg/kg (+)-22a alone did not affect PPI relative to the Veh + Veh controls. Mice administered Veh + AMPH had a marked reduction in PPI. Treatment with $0.5,1$, or $2 \mathrm{mg} / \mathrm{kg}(+)-22 \mathrm{a}$ restored overall AMPH-disrupted PPI to the levels of the Veh + Veh group, with $1 \mathrm{mg} / \mathrm{kg}$ fully rescuing the prepulse dependency of the response. Mice given the $4 \mathrm{mg} / \mathrm{kg}$ dose + AMPH showed a reduction in PPI similar to that found in Veh + AMPH animals. $N=8-11$ mice/treatment; $*, p<0.05$, compared to the Veh + Veh control; \#, $p<0.05$, compared to the Veh + AMPH group; $\neq, p<0.05$, within treatment for 8 or $12 \mathrm{~dB}$ compared to the $4 \mathrm{~dB}$ response; $\S, p<0.05$, within treatment for $12 \mathrm{~dB}$ compared to the $8 \mathrm{~dB}$ response. (B) Pulse-only responses during PPI testing were not affected by treatment in the (+)-22a + Veh or the Veh + AMPH groups, but when $(+)-\mathbf{2 2 a}$ was given before AMPH, the startle-only response was attenuated in the 0.5 and $2 \mathrm{mg} / \mathrm{kg}(+)-22$ a groups. $N=8-11 \mathrm{mice} / \mathrm{treatment} ; *, p<0.05$, compared to the Veh + Veh control; \#, $p<0.05$, compared to the Veh + AMPH group;,$+ p<0.05$ compared to $4 \mathrm{mg} / \mathrm{kg}(+)-22 \mathrm{a}+\mathrm{Veh}$ treatment; $\dagger, p<0.05$ compared to the $4 \mathrm{mg} / \mathrm{kg}(+)-22 \mathrm{a}+\mathrm{AMPH}$ treatment.

A

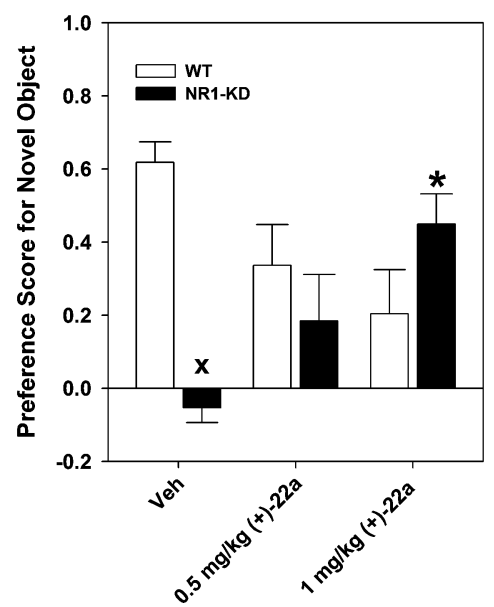

B

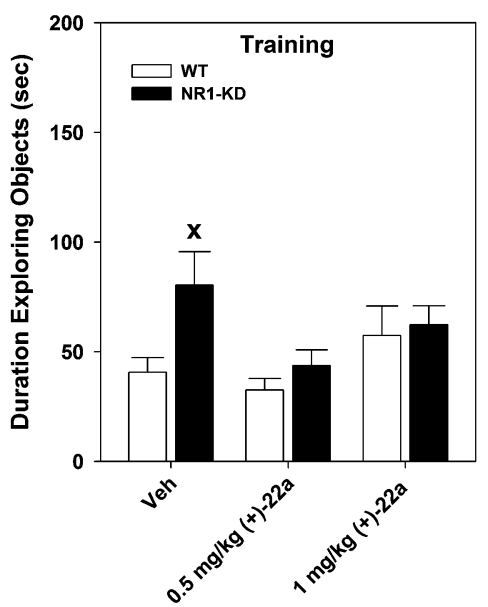

C

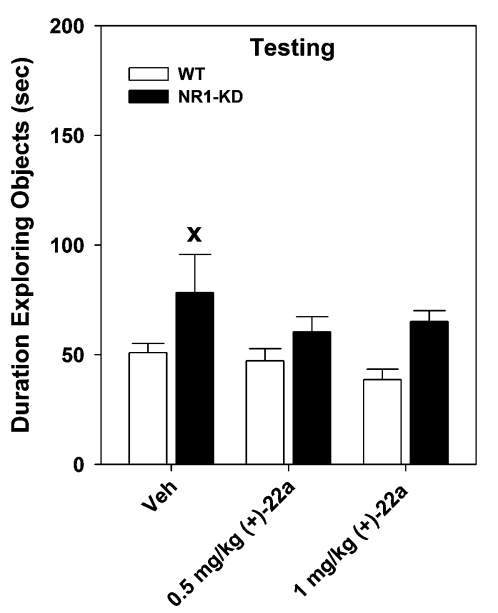

Figure 5. Compound (+)-22a rescues novel object recognition memory in NR1-KD mice. Mice were given vehicle (Veh) or $0.5 \mathrm{or} 1 \mathrm{mg} / \mathrm{kg}(+)-22 \mathrm{a}$ 30 min before training or at testing for long-term memory (LTM). (A) At testing for LTM, Veh-treated wild-type (WT) controls displayed a preference for the novel object, whereas NR1-KD mice showed no preference for either object. In contrast, $1 \mathrm{mg} / \mathrm{kg}(+)-22 \mathrm{a}$ rescued this deficit in the mutants while producing some deficiency in the WT animals. (B, C) As a control, the duration of object exploration was examined during (B) training and (C) LTM testing. At training and at testing, Veh-treated NR1-KD mice spent more time exploring the objects than WT mice, while (+)-22a reduced this exploration time to levels that were not significantly different from the WT controls. $N=9-10$ mice/genotype/treatment; $*, p<0.05,(+)-22 \mathrm{a}$ compared to the Veh within genotype; ${ }^{\mathrm{x}}, p<0.05$, NR1-KD compared to the WT vehicle.

some assays and low inhibition of the most abundant CYP isoforms. It inhibits the hERG channel with moderate potency $\left(\mathrm{IC}_{50}=9.1 \mu \mathrm{M}\right)$. However, a brain penetration study in mice indicated high brain concentration/plasma concentration ratios at $0.5 \mathrm{~h}(29.9)$ and $2.0 \mathrm{~h}(45.0)$, respectively.

Compound (+)-22a showed efficacy in schizophrenia-related behavioral models. In the hyperdopaminergic model, it suppressed AMPH-induced hyperlocomotion in the open field in a dose-dependent manner, and it normalized the AMPH-disrupted PPI. Furthermore, it rescued NORM in the NR1-KD mice in the hypoglutamatergic model. Catalepsy was very low with compound (+)-22a, as it showed effects similar to that of the vehicle control and was significantly lower than that for haloperidol. Although species differences at the 5- $\mathrm{HT}_{2 \mathrm{~A}}$ receptor have been reported to influence the in vivo translation of $5-\mathrm{HT}_{2 \mathrm{C}}$ selective agonists, ${ }^{44}$ ultimately we are interested in the human species $5-\mathrm{HT}_{2}$ receptor selectivity. Considering that $5-\mathrm{HT}_{2 \mathrm{~A}}$ agonists disrupt rather than normalize PPI and that $5-\mathrm{HT}_{2 \mathrm{~A}}$ antagonists rather than agonists suppress $\mathrm{AMPH}$-induced hyperlocomotion, ${ }^{45,46}$ our results with compound (+)-22a likely 


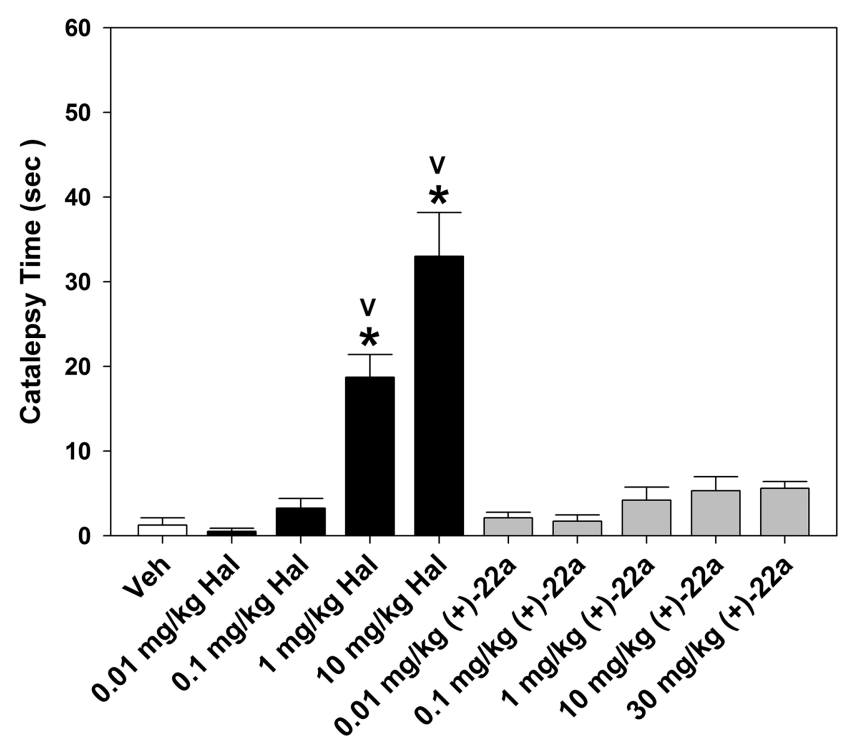

Figure 6. Comparison of catalepsy induced by haloperidol and (+)-22a in C57BL/6J mice with the horizontal bar test. Separate groups of mice were injected with vehicle (Veh), or $0.01,0.1,1$, or $10 \mathrm{mg} / \mathrm{kg}$ haloperidol (Hal), or $0.01,0.1,1,10$, or $30 \mathrm{mg} / \mathrm{kg}$ compound (+)-22a and evaluated for catalepsy $60 \mathrm{~min}$ later. $N=8-10$ mice/treatment; $*, p<0.05$, compared to the Veh control; ${ }^{\mathrm{V}}, p<0.05$, compared to all other groups.

do not reflect $5-\mathrm{HT}_{2 \mathrm{~A}}$ activation resulting from species differences in rodent models of schizophrenia. Taken together, these data support the further development of compound (+)-22a as a potential drug candidate for the treatment of schizophrenia. This agent may cause fewer side effects while improving cognition and avoiding weight gain in schizophrenia patients based upon its $5-\mathrm{HT}_{2 \mathrm{C}}$-directed mechanism of action.

\section{EXPERIMENTAL SECTION}

General. All chemicals and solvents were purchased from SigmaAldrich or Fisher Scientific and were used as obtained without further purification. Microwave reactions were run in a Biotage Initiator microwave reactor. Synthetic intermediates were purified by CombiFlash flash chromatography on $230-400$ mesh silica gel. ${ }^{1} \mathrm{H}$ and ${ }^{13} \mathrm{C}$ NMR spectra were recorded on Bruker DPX-400 or AVANCE-400 spectrometers, at 400 and $100 \mathrm{MHz}$, respectively. NMR chemical shifts were reported in $\delta$ (ppm) using residual solvent peaks as standard $\left(\mathrm{CDCl}_{3} 7.26(\mathrm{H}), 77.23(\mathrm{C}) ; \mathrm{CD}_{3} \mathrm{OD} 3.31(\mathrm{H}), 49.15(\mathrm{C})\right.$; DMSO- $d_{6}$ $2.50(\mathrm{H}), 39.52(\mathrm{C}))$. Mass spectra were measured using ESI with an LCMS-IT-TOF (Shimadzu). Purity of all final compounds (greater than 95\%) was determined by analytical HPLC (ACE 3AQ $\mathrm{C}_{18}$ column $(150 \times 4.6 \mathrm{~mm}$, particle size $3 \mu \mathrm{M})$; $0.05 \%$ TFA in $\mathrm{H}_{2} \mathrm{O} / 0.05 \%$ TFA in $\mathrm{MeOH}$ gradient eluting system; flow rate $=1.0 \mathrm{~mL} / \mathrm{min}$ ). Optical rotation values were recorded on a Rudolph Research Autopol IV automatic polarimeter.

Compounds $16 \mathrm{a}-\mathrm{g}, 18 \mathrm{a}-\mathrm{g}$, and $19 \mathrm{a}-\mathrm{g}$ were prepared according to the methods depicted in Scheme 1. The synthetic procedures and characterization data of all intermediates can be found in the Supporting Information.

General Methods. (1) Chiral HPLC separation of racemic 16a-g, $18 \mathrm{a}-\mathrm{g}$, and $19 \mathrm{a}-\mathrm{g}$. Analytical conditions: RegisCell chiral column $(25 \mathrm{~cm} \times 4.6 \mathrm{~mm}, 10 \mu \mathrm{m}$ particle size), $1.5-15 \% \mathrm{EtOH}$ in $n$-hexane as the mobile phase; preparative conditions: RegisPack chiral column ( $25 \mathrm{~cm} \times 21.1 \mathrm{~mm}, 10 \mu \mathrm{m}$ particle size $), 3.0-7.5 \% \mathrm{EtOH}$ in $n$-hexane as the eluting system (isocratic eluent, stacked injections, flow rate = $18 \mathrm{~mL} / \mathrm{min}, \lambda=254$ and $280 \mathrm{~nm}$ ). Optical purities of both enantiomers were determined with analytical HPLC after the separation, and a second separation was performed when necessary to guarantee an enantiomeric excess of $>90 \%$. (2) Both enantiomers of compounds $16 \mathrm{a}-\mathrm{g}, 19 \mathrm{a}-\mathrm{g}$, and $21 \mathrm{a}-\mathrm{g}$ were dissolved in $2 \mathrm{M} \mathrm{HCl}$ in diethyl ether and stirred at room temperature for 24-48 h. The white solids formed were collected by filtration, washed with diethyl ether, and dried under vacuum to give compounds (-)-20a-g, (+)-20a-g, (-)-21a-g, $(+)-21 \mathbf{a}-\mathbf{g},(-)-22 \mathbf{a}-\mathbf{g}$, and $(+)-22 \mathbf{a}-\mathbf{g}$ as $\mathrm{HCl}$ salts.

(-)-[2-(4,5-Difluoro-2-methoxyphenyl)cyclopropyl]methanamine Hydrochloride ((-)-20a). White solid. HPLC: 99.8\%; ${ }^{1} \mathrm{H}$ NMR $\left(\mathrm{CD}_{3} \mathrm{OD}\right) \delta$ 6.94-6.88 $(\mathrm{m}, 2 \mathrm{H}), 3.87(\mathrm{~s}, 3 \mathrm{H}), 3.08(\mathrm{dd}, J=13.2$, $7.2 \mathrm{~Hz}, 1 \mathrm{H}), 2.93(\mathrm{dd}, J=13.2,8.0 \mathrm{~Hz}, 1 \mathrm{H}), 2.09-2.03(\mathrm{~m}, 1 \mathrm{H}), 1.27-$ $1.23(\mathrm{~m}, 1 \mathrm{H}), 1.13-1.08(\mathrm{~m}, 1 \mathrm{H}), 1.04-1.00(\mathrm{~m}, 1 \mathrm{H}) ;{ }^{13} \mathrm{C}$ NMR $\left(\mathrm{CD}_{3} \mathrm{OD}\right) \delta 156.2\left(\mathrm{~d}, J_{\mathrm{CF}}=7.4 \mathrm{~Hz}\right), 150.2\left(\mathrm{dd}, J_{\mathrm{CF}}=242.7,13.5 \mathrm{~Hz}\right)$, $145.5\left(\mathrm{dd}, J_{\mathrm{CF}}=236.5,12.6 \mathrm{~Hz}\right), 127.1,116.4\left(\mathrm{~d}, J_{\mathrm{CF}}=19.2 \mathrm{~Hz}\right), 101.6$ $\left(\mathrm{d}, J_{\mathrm{CF}}=21.4 \mathrm{~Hz}\right), 56.9,45.1,19.5,17.8,13.1$; HRMS calcd for $\mathrm{C}_{11} \mathrm{H}_{14} \mathrm{~F}_{2} \mathrm{NO}^{+}\left([\mathrm{M}+\mathrm{H}]^{+}\right): 214.1038$, found: $214.1035 ;[\alpha]_{\mathrm{D}}{ }^{20}-7.9$ (c $0.7, \mathrm{MeOH})$.

(+)-[2-(4,5-Difluoro-2-methoxyphenyl)cyclopropyl]methanamine Hydrochloride ((+)-20a). White solid. HPLC: 99.8\%; ${ }^{1} \mathrm{H}$ NMR $\left(\mathrm{CD}_{3} \mathrm{OD}\right) \delta$ 6.94-6.88 (m, 2H), $3.87(\mathrm{~s}, 3 \mathrm{H}), 3.08(\mathrm{dd}, J=13.2$, $7.2 \mathrm{~Hz}, 1 \mathrm{H}), 2.93(\mathrm{dd}, J=13.2,8.0 \mathrm{~Hz}, 1 \mathrm{H}), 2.08-2.03(\mathrm{~m}, 1 \mathrm{H}), 1.26-$ $1.22(\mathrm{~m}, 1 \mathrm{H}), 1.14-1.08(\mathrm{~m}, 1 \mathrm{H}), 1.04-0.98(\mathrm{~m}, 1 \mathrm{H})$; HRMS calcd for $\mathrm{C}_{11} \mathrm{H}_{14} \mathrm{~F}_{2} \mathrm{NO}^{+}\left([\mathrm{M}+\mathrm{H}]^{+}\right): 214.1038$, found: 214.1030; $[\alpha]_{\mathrm{D}}{ }^{20}+6.0$ (c $0.2, \mathrm{MeOH})$.

(-)-[2-(2,3-Difluoro-6-methoxyphenyl)cyclopropyl]methanamine Hydrochloride ((-)-20b). White solid. HPLC: 99.6\%; ${ }^{1} \mathrm{H}$ NMR $\left(\mathrm{CD}_{3} \mathrm{OD}\right) \delta 7.08(\mathrm{q}, J=9.6 \mathrm{~Hz}, 1 \mathrm{H}), 6.74-6.71(\mathrm{~m}, 1 \mathrm{H}), 3.86(\mathrm{~s}$, $3 \mathrm{H}), 3.13(\mathrm{dd}, J=13.2,6.8 \mathrm{~Hz}, 1 \mathrm{H}), 2.92(\mathrm{dd}, J=13.2,8.4 \mathrm{~Hz}, 1 \mathrm{H})$, $1.85-1.79(\mathrm{~m}, 1 \mathrm{H}), 1.54-1.47(\mathrm{~m}, 1 \mathrm{H}), 1.27-1.21(\mathrm{~m}, 1 \mathrm{H}), 1.11-1.05$ $(\mathrm{m}, 1 \mathrm{H}) ;{ }^{13} \mathrm{C} \mathrm{NMR}\left(\mathrm{CD}_{3} \mathrm{OD}\right) \delta 156.7\left(\mathrm{dd}, J_{\mathrm{CF}}=5.8,2.0 \mathrm{~Hz}\right), 151.3(\mathrm{dd}$, $\left.J_{\mathrm{CF}}=243.3,13.8 \mathrm{~Hz}\right), 146.7\left(\mathrm{dd}, J_{\mathrm{CF}}=237.2,13.9 \mathrm{~Hz}\right), 119.3\left(\mathrm{~d}, J_{\mathrm{CF}}=\right.$ $11.4 \mathrm{~Hz}), 115.6\left(\mathrm{~d}, J_{\mathrm{CF}}=18.3 \mathrm{~Hz}\right), 106.8\left(\mathrm{dd}, J_{\mathrm{CF}}=6.4,3.5 \mathrm{~Hz}\right), 56.8$, 45.4, 18.3, 13.6, 12.9; HRMS calcd for $\mathrm{C}_{11} \mathrm{H}_{14} \mathrm{~F}_{2} \mathrm{NO}^{+}\left([\mathrm{M}+\mathrm{H}]^{+}\right)$: 214.1038, found: 214.1044; $[\alpha]_{\mathrm{D}}{ }^{20}-36.9(c 0.7, \mathrm{MeOH})$.

(+)-[2-(2,3-Difluoro-6-methoxyphenyl)cyclopropyl]methanamine Hydrochloride ((+)-20b). White solid. HPLC: 99.8\%; ${ }^{1} \mathrm{H}$ NMR $\left(\mathrm{CD}_{3} \mathrm{OD}\right) \delta 7.08(\mathrm{q}, J=9.6 \mathrm{~Hz}, 1 \mathrm{H}), 6.75-6.71(\mathrm{~m}, 1 \mathrm{H}), 3.86(\mathrm{~s}$, $3 \mathrm{H}), 3.13(\mathrm{dd}, J=12.8,6.8 \mathrm{~Hz}, 1 \mathrm{H}), 2.91(\mathrm{dd}, J=12.8,8.4 \mathrm{~Hz}, 1 \mathrm{H})$, $1.85-1.79(\mathrm{~m}, 1 \mathrm{H}), 1.51-1.46(\mathrm{~m}, 1 \mathrm{H}), 1.27-1.22(\mathrm{~m}, 1 \mathrm{H}), 1.10-1.05$ $(\mathrm{m}, 1 \mathrm{H})$; HRMS calcd for $\mathrm{C}_{11} \mathrm{H}_{14} \mathrm{~F}_{2} \mathrm{NO}^{+}\left([\mathrm{M}+\mathrm{H}]^{+}\right): 214.1038$, found: 214.1041; $[\alpha]_{\mathrm{D}}^{20}+38.0($ c $0.2, \mathrm{MeOH})$.

(-)-[2-(5-Chloro-4-fluoro-2-methoxyphenyl)cyclopropyl]methanamine Hydrochloride ((-)-20c). White solid. HPLC: 99.2\%; ${ }^{1} \mathrm{H} \mathrm{NMR}\left(\mathrm{CD}_{3} \mathrm{OD}\right) \delta 7.06(\mathrm{~d}, J=8.4 \mathrm{~Hz}, 1 \mathrm{H}), 6.91(\mathrm{~d}, J=11.2 \mathrm{~Hz}, 1 \mathrm{H})$, $3.89(\mathrm{~s}, 3 \mathrm{H}), 3.08(\mathrm{dd}, J=13.2,7.2 \mathrm{~Hz}, 1 \mathrm{H}), 2.93(\mathrm{dd}, J=13.2,8.0 \mathrm{~Hz}$, $1 \mathrm{H}), 2.06-2.00(\mathrm{~m}, 1 \mathrm{H}), 1.29-1.21(\mathrm{~m}, 1 \mathrm{H}), 1.13-1.08(\mathrm{~m}, 1 \mathrm{H})$, $1.04-0.98(\mathrm{~m}, 1 \mathrm{H}) ;{ }^{13} \mathrm{C}$ NMR $\left(\mathrm{CD}_{3} \mathrm{OD}\right) \delta 159.8,158.6\left(\mathrm{~d}, J_{\mathrm{CF}}=235.0\right.$ $\mathrm{Hz}), 129.2,128.0,112.0\left(\mathrm{~d}, J_{\mathrm{CF}}=17.9 \mathrm{~Hz}\right), 101.2\left(\mathrm{~d}, J_{\mathrm{CF}}=25.4 \mathrm{~Hz}\right)$, 56.8, 45.1, 19.3, 17.7, 12.9; HRMS (ESI) $m / z$ calcd for $\mathrm{C}_{11} \mathrm{H}_{14} \mathrm{ClFNO}^{+}$ $\left([\mathrm{M}+\mathrm{H}]^{+}\right): 230.0742$, found: $230.0719 ;[\alpha]_{\mathrm{D}}{ }^{20}-37.4(c 0.5, \mathrm{MeOH})$.

(+)-[2-(5-Chloro-4-fluoro-2-methoxyphenyl)cyclopropyl]methanamine Hydrochloride ((+)-20c). White solid. HPLC: 99.7\%; ${ }^{1} \mathrm{H} \mathrm{NMR}\left(\mathrm{CD}_{3} \mathrm{OD}\right) \delta 7.06(\mathrm{~d}, J=8.4 \mathrm{~Hz}, 1 \mathrm{H}), 6.91(\mathrm{~d}, J=11.2 \mathrm{~Hz}, 1 \mathrm{H})$, $3.89(\mathrm{~s}, 3 \mathrm{H}), 3.08(\mathrm{dd}, J=13.2,7.2 \mathrm{~Hz}, 1 \mathrm{H}), 2.92(\mathrm{dd}, J=13.2,8.0 \mathrm{~Hz}$, $1 \mathrm{H}), 2.06-2.00(\mathrm{~m}, 1 \mathrm{H}), 1.28-1.21(\mathrm{~m}, 1 \mathrm{H}), 1.14-1.08(\mathrm{~m}, 1 \mathrm{H})$, $1.04-0.98(\mathrm{~m}, 1 \mathrm{H}) ;{ }^{13} \mathrm{C}$ NMR $\left(\mathrm{CD}_{3} \mathrm{OD}\right) \delta 159.8,158.6\left(\mathrm{~d}, J_{\mathrm{CF}}=234.8\right.$ $\mathrm{Hz}), 129.2,128.0,112.1\left(\mathrm{~d}, J_{\mathrm{CF}}=17.8 \mathrm{~Hz}\right), 101.2\left(\mathrm{~d}, J_{\mathrm{CF}}=25.7 \mathrm{~Hz}\right)$, 56.8, 45.1, 19.3, 17.7, 12.9; HRMS (ESI) $\mathrm{m} / z$ calcd for $\mathrm{C}_{11} \mathrm{H}_{14} \mathrm{ClFNO}^{+}$ $\left([\mathrm{M}+\mathrm{H}]^{+}\right): 230.0742$, found: $230.0724 ;[\alpha]_{\mathrm{D}}{ }^{20}+35.6(c 0.5, \mathrm{MeOH})$.

(-)-[2-(3-Chloro-2-fluoro-6-methoxyphenyl)cyclopropyl]methanamine Hydrochloride ((-)-20d). White solid. HPLC: 98.9\%; ${ }^{1} \mathrm{H} \mathrm{NMR}\left(\mathrm{CD}_{3} \mathrm{OD}\right) \delta 7.28(\mathrm{t}, J=8.8 \mathrm{~Hz}, 1 \mathrm{H}), 6.79(\mathrm{dd}, J=9.2,1.6 \mathrm{~Hz}$, $1 \mathrm{H}), 3.87(\mathrm{~s}, 3 \mathrm{H}), 3.11(\mathrm{dd}, J=13.2,6.8 \mathrm{~Hz}, 1 \mathrm{H}), 2.90(\mathrm{dd}, J=13.2$, $8.0 \mathrm{~Hz}, 1 \mathrm{H}), 1.82-1.76(\mathrm{~m}, 1 \mathrm{H}), 1.48-1.43(\mathrm{~m}, 1 \mathrm{H}), 1.23-1.18(\mathrm{~m}$, $1 \mathrm{H}), 1.09-1.03(\mathrm{~m}, 1 \mathrm{H}) ;{ }^{13} \mathrm{C} \mathrm{NMR}\left(\mathrm{CD}_{3} \mathrm{OD}\right) \delta 160.1\left(\mathrm{~d}, J_{\mathrm{CF}}=6.6 \mathrm{~Hz}\right)$, $158.7\left(\mathrm{~d}, J_{\mathrm{CF}}=243.8 \mathrm{~Hz}\right), 129.6,118.9\left(\mathrm{~d}, J_{\mathrm{CF}}=20.1 \mathrm{~Hz}\right), 113.9\left(\mathrm{~d}, J_{\mathrm{CF}}=\right.$ $19.3 \mathrm{~Hz}$ ), 108.5, 56.8, 45.4, 18.4, 13.7, 13.1; HRMS (ESI) $\mathrm{m} / z$ calcd for $\mathrm{C}_{11} \mathrm{H}_{14} \mathrm{ClFNO}^{+}\left([\mathrm{M}+\mathrm{H}]^{+}\right): 230.0742$, found: $230.0740 ;[\alpha]_{\mathrm{D}}{ }^{20}-54.0$ (c $0.15, \mathrm{MeOH})$.

(+)-[2-(3-Chloro-2-fluoro-6-methoxyphenyl)cyclopropyl]methanamine Hydrochloride ((+)-20d). White solid. HPLC: 99.4\%; ${ }^{1} \mathrm{H} \operatorname{NMR}\left(\mathrm{CD}_{3} \mathrm{OD}\right) \delta 7.29(\mathrm{t}, J=8.8 \mathrm{~Hz}, 1 \mathrm{H}), 6.79(\mathrm{dd}, J=8.8,1.6 \mathrm{~Hz}$, $1 \mathrm{H}), 3.88(\mathrm{~s}, 3 \mathrm{H}), 3.11(\mathrm{dd}, J=12.8,6.4 \mathrm{~Hz}, 1 \mathrm{H}), 2.90(\mathrm{dd}, J=12.8$, 
$8.4 \mathrm{~Hz}, 1 \mathrm{H}), 1.82-1.77(\mathrm{~m}, 1 \mathrm{H}), 1.48-1.44(\mathrm{~m}, 1 \mathrm{H}), 1.24-1.18(\mathrm{~m}$, $1 \mathrm{H}), 1.09-1.04(\mathrm{~m}, 1 \mathrm{H}) ;{ }^{13} \mathrm{C} \mathrm{NMR}\left(\mathrm{CD}_{3} \mathrm{OD}\right) \delta 160.1\left(\mathrm{~d}, J_{\mathrm{CF}}=6.6 \mathrm{~Hz}\right)$, $158.7\left(\mathrm{~d}, J_{\mathrm{CF}}=243.8 \mathrm{~Hz}\right), 129.6,118.9\left(\mathrm{~d}, J_{\mathrm{CF}}=20.1 \mathrm{~Hz}\right), 113.8\left(\mathrm{~d}, J_{\mathrm{CF}}=\right.$ $19.3 \mathrm{~Hz}$ ), 108.4, 56.8, 45.4, 18.4, 13.7, 13.0; HRMS (ESI) $\mathrm{m} / \mathrm{z}$ calcd for $\mathrm{C}_{11} \mathrm{H}_{14} \mathrm{ClFNO}^{+}\left([\mathrm{M}+\mathrm{H}]^{+}\right): 230.0742$, found: $230.0744 ;[\alpha]_{\mathrm{D}}{ }^{20}+50.0$ (c $0.1, \mathrm{MeOH})$.

(-)-[2-(4,5-Dichloro-2-methoxyphenyl)cyclopropyl]methanamine Hydrochloride ((-)-20e). White solid. HPLC: 99.6\%; ${ }^{1} \mathrm{H}$ NMR $\left(\mathrm{CD}_{3} \mathrm{OD}\right) \delta 7.11(\mathrm{~s}, 2 \mathrm{H}), 3.88(\mathrm{~s}, 3 \mathrm{H}), 3.08(\mathrm{dd}, J=13.2$, $7.2 \mathrm{~Hz}, 1 \mathrm{H}), 2.92(\mathrm{dd}, J=13.2,8.0 \mathrm{~Hz}, 1 \mathrm{H}), 2.09-2.04(\mathrm{~m}, 1 \mathrm{H}), 1.28-$ $1.26(\mathrm{~m}, 1 \mathrm{H}), 1.16-1.10(\mathrm{~m}, 1 \mathrm{H}), 1.06-1.00(\mathrm{~m}, 1 \mathrm{H}) ;{ }^{13} \mathrm{C} \mathrm{NMR}$ $\left(\mathrm{CD}_{3} \mathrm{OD}\right) \delta 159.1,131.6,131.5129 .2,124.5,113.7,56.8,45.0,19.5$, 17.8, 13.2; HRMS (ESI) $m / z$ calcd for $\mathrm{C}_{11} \mathrm{H}_{14} \mathrm{Cl}_{2} \mathrm{NO}^{+}\left([\mathrm{M}+\mathrm{H}]^{+}\right)$: 246.0447, found: 246.0438; $[\alpha]_{\mathrm{D}}{ }^{20}-37.4(c 0.3, \mathrm{MeOH})$.

(+)-[2-(4,5-Dichloro-2-methoxyphenyl)cyclopropyl]methanamine Hydrochloride ((+)-20e). White solid. HPLC: 99.7\%; ${ }^{1} \mathrm{H}$ NMR $\left(\mathrm{CD}_{3} \mathrm{OD}\right) \delta 7.11(\mathrm{~s}, 2 \mathrm{H}), 3.89(\mathrm{~s}, 3 \mathrm{H}), 3.08(\mathrm{dd}, J=13.2$, $7.6 \mathrm{~Hz}, 1 \mathrm{H}), 2.93(\mathrm{dd}, J=12.8,8.0 \mathrm{~Hz}, 1 \mathrm{H}), 2.09-2.04(\mathrm{~m}, 1 \mathrm{H}), 1.29-$ $1.26(\mathrm{~m}, 1 \mathrm{H}), 1.15-1.10(\mathrm{~m}, 1 \mathrm{H}), 1.06-1.02(\mathrm{~m}, 1 \mathrm{H}) ;{ }^{13} \mathrm{C} \mathrm{NMR}$ $\left(\mathrm{CD}_{3} \mathrm{OD}\right) \delta 159.1,131.6,131.5,129.2,124.5,113.7,56.8,45.0,19.5$, 17.8, 13.2; HRMS (ESI) $m / z$ calcd for $\mathrm{C}_{11} \mathrm{H}_{14} \mathrm{Cl}_{2} \mathrm{NO}^{+}\left([\mathrm{M}+\mathrm{H}]^{+}\right)$: 246.0447, found: 246.0441; $[\alpha]_{\mathrm{D}}{ }^{20}+37.7(c 0.4, \mathrm{MeOH})$.

(-)-[2-(2,3-Dichloro-6-methoxyphenyl)cyclopropyl]methanamine Hydrochloride ((-)-20f). White solid. HPLC: 99.9\%; ${ }^{1} \mathrm{H} \mathrm{NMR}\left(\mathrm{CD}_{3} \mathrm{OD}\right) \delta 7.40(\mathrm{~d}, J=8.8 \mathrm{~Hz}, 1 \mathrm{H}), 6.96(\mathrm{~d}, J=8.8 \mathrm{~Hz}, 1 \mathrm{H})$, $3.88(\mathrm{~s}, 3 \mathrm{H}), 3.06(\mathrm{~d}, J=7.2 \mathrm{~Hz}, 2 \mathrm{H}), 1.78-1.73(\mathrm{~m}, 1 \mathrm{H}), 1.44-1.40$ (m, $1 \mathrm{H}), 1.21-1.15(\mathrm{~m}, 1 \mathrm{H}), 1.11-1.06(\mathrm{~m}, 1 \mathrm{H}) ;{ }^{13} \mathrm{C} \mathrm{NMR}\left(\mathrm{CD}_{3} \mathrm{OD}\right)$ $\delta$ 159.9, 135.9, 130.2, 129.6, 125.7, 111.7, 56.7, 45.4, 20.1, 18.3, 15.2; HRMS (ESI) $m / z$ calcd for $\mathrm{C}_{11} \mathrm{H}_{14} \mathrm{Cl}_{2} \mathrm{NO}^{+}\left([\mathrm{M}+\mathrm{H}]^{+}\right): 246.0447$, found: 246.0449; $[\alpha]_{\mathrm{D}}{ }^{20}-62.0(c 0.1, \mathrm{MeOH})$.

(+)-[2-(2,3-Dichloro-6-methoxyphenyl)cyclopropyl]methanamine Hydrochloride ((+)-20f). White solid. HPLC: $99.8 \% ;{ }^{1} \mathrm{H}$ $\operatorname{NMR}\left(\mathrm{CD}_{3} \mathrm{OD}\right) \delta 7.40(\mathrm{~d}, J=9.2 \mathrm{~Hz}, 1 \mathrm{H}), 6.96(\mathrm{~d}, J=9.2 \mathrm{~Hz}, 1 \mathrm{H}), 3.88$ $(\mathrm{s}, 3 \mathrm{H}), 3.06(\mathrm{~d}, J=7.2 \mathrm{~Hz}, 2 \mathrm{H}), 1.77-1.74(\mathrm{~m}, 1 \mathrm{H}), 1.44-1.42(\mathrm{~m}$, $1 \mathrm{H}), 1.21-1.15(\mathrm{~m}, 1 \mathrm{H}), 1.09-1.05(\mathrm{~m}, 1 \mathrm{H}) ;{ }^{13} \mathrm{C} \mathrm{NMR}\left(\mathrm{CD}_{3} \mathrm{OD}\right) \delta$ $159.9,135.9,130.2,129.6,125.7,111.7,56.7,45.4,20.1,18.3,15.2$; HRMS (ESI) $m / z$ calcd for $\mathrm{C}_{11} \mathrm{H}_{14} \mathrm{Cl}_{2} \mathrm{NO}^{+}\left([\mathrm{M}+\mathrm{H}]^{+}\right): 246.0447$, found: 246.0448; $[\alpha]_{\mathrm{D}}{ }^{20}+69.0(c 0.2, \mathrm{MeOH})$.

(-)-[2-(2-Chloro-3-fluoro-6-methoxyphenyl)cyclopropyl]methanamine Hydrochloride ((-)-20g). White solid. HPLC: 99.7\%; ${ }^{1} \mathrm{H}$ NMR $\left(\mathrm{CD}_{3} \mathrm{OD}\right) \delta 7.10(\mathrm{t}, J=8.8 \mathrm{~Hz}, 1 \mathrm{H}), 6.92(\mathrm{dd}, J=9.2,4.4 \mathrm{~Hz}$, $1 \mathrm{H}), 3.86(\mathrm{~s}, 3 \mathrm{H}), 3.10-3.00(\mathrm{~m}, 2 \mathrm{H}), 1.76-1.73(\mathrm{~m}, 1 \mathrm{H}), 1.47-1.42$ $(\mathrm{m}, 1 \mathrm{H}), 1.19-1.08(\mathrm{~m}, 2 \mathrm{H}) ;{ }^{13} \mathrm{C}$ NMR $\left(\mathrm{CD}_{3} \mathrm{OD}\right) \delta 157.1,154.2$ $\left(\mathrm{d}, J_{\mathrm{CF}}=237.8 \mathrm{~Hz}\right), 129.1,124.6\left(\mathrm{~d}, J_{\mathrm{CF}}=18.2 \mathrm{~Hz}\right), 115.5\left(\mathrm{~d}, J_{\mathrm{CF}}=22.9\right.$ $\mathrm{Hz}), 111.1\left(\mathrm{~d}, J_{\mathrm{CF}}=8.5 \mathrm{~Hz}\right), 56.8,45.4,19.6,17.5,14.7$; HRMS (ESI) $\mathrm{m} / z$ calcd for $\mathrm{C}_{11} \mathrm{H}_{14} \mathrm{ClFNO}^{+}\left([\mathrm{M}+\mathrm{H}]^{+}\right): 230.0742$, found: 230.0723 ; $[\alpha]_{\mathrm{D}}{ }^{20}-66.4(c 0.3, \mathrm{MeOH})$.

(+)-[2-(2-Chloro-3-fluoro-6-methoxyphenyl)cyclopropyl]methanamine Hydrochloride ((+)-20g). White solid. HPLC: 99.6\%; ${ }^{1} \mathrm{H}$ NMR $\left(\mathrm{CD}_{3} \mathrm{OD}\right) \delta 7.10(\mathrm{t}, J=8.8 \mathrm{~Hz}, 1 \mathrm{H}), 6.92(\mathrm{dd}, J=9.2,4.4 \mathrm{~Hz}$, $1 \mathrm{H}), 3.86(\mathrm{~s}, 3 \mathrm{H}), 3.10-3.00(\mathrm{~m}, 2 \mathrm{H}), 1.76-1.73(\mathrm{~m}, 1 \mathrm{H}), 1.47-1.43$ $(\mathrm{m}, 1 \mathrm{H}), 1.19-1.07(\mathrm{~m}, 2 \mathrm{H}) ;{ }^{13} \mathrm{C} \mathrm{NMR}\left(\mathrm{CD}_{3} \mathrm{OD}\right) \delta 157.1,154.2\left(\mathrm{~d}, J_{\mathrm{CF}}\right.$ $=237.9 \mathrm{~Hz}), 129.1,124.6\left(\mathrm{~d}, J_{\mathrm{CF}}=18.1 \mathrm{~Hz}\right), 115.5\left(\mathrm{~d}, J_{\mathrm{CF}}=22.9 \mathrm{~Hz}\right)$, $111.1\left(\mathrm{~d}, J_{\mathrm{CF}}=8.4 \mathrm{~Hz}\right), 56.8,45.4,19.6,17.5,14.7$; HRMS (ESI) $\mathrm{m} / z$ calcd for $\mathrm{C}_{11} \mathrm{H}_{14} \mathrm{ClFNO}^{+}\left([\mathrm{M}+\mathrm{H}]^{+}\right): 230.0742$, found: 230.0758 ; $[\alpha]_{\mathrm{D}}^{20}+69.4(c 0.3, \mathrm{MeOH})$.

(-)-[2-[4,5-Difluoro-2-(2-fluoroethoxy)phenyl]cyclopropyl]methanamine Hydrochloride ((-)-21a). White solid. HPLC: 99.7\%; ${ }^{1} \mathrm{H}$ NMR $\left(\mathrm{CD}_{3} \mathrm{OD}\right) \delta 6.99-6.93(\mathrm{~m}, 2 \mathrm{H}), 4.88-4.74(\mathrm{~m}, 2 \mathrm{H}), 4.32-$ $4.22(\mathrm{~m}, 2 \mathrm{H}), 3.03-3.00(\mathrm{~m}, 2 \mathrm{H}), 2.11-2.08(\mathrm{~m}, 1 \mathrm{H}), 1.25-1.15$ $(\mathrm{m}, 2 \mathrm{H}), 1.05-1.01(\mathrm{~m}, 1 \mathrm{H}) ;{ }^{13} \mathrm{C} \mathrm{NMR}\left(\mathrm{CD}_{3} \mathrm{OD}\right) \delta 155.0\left(\mathrm{dd}, J_{\mathrm{CF}}=\right.$ 7.4, 2.0 Hz), $150.1\left(\mathrm{dd}, J_{\mathrm{CF}}=243.0,13.5 \mathrm{~Hz}\right), 145.8\left(\mathrm{dd}, J_{\mathrm{CF}}=237.3\right.$, $12.6 \mathrm{~Hz}), 127.6,116.6\left(\mathrm{~d}, J_{\mathrm{CF}}=19.5 \mathrm{~Hz}\right), 102.9\left(\mathrm{~d}, J_{\mathrm{CF}}=21.4 \mathrm{~Hz}\right), 83.4$ $\left(\mathrm{d}, J_{\mathrm{CF}}=166.9 \mathrm{~Hz}\right), 69.9\left(\mathrm{~d}, J_{\mathrm{CF}}=18.8 \mathrm{~Hz}\right), 44.9,19.7,17.8,12.8$; HRMS calcd for $\mathrm{C}_{12} \mathrm{H}_{15} \mathrm{~F}_{3} \mathrm{NO}^{+}\left([\mathrm{M}+\mathrm{H}]^{+}\right): 246.1100$, found: 246.1106; $[\alpha]_{\mathrm{D}}{ }^{20}$ $-1.5($ c $0.4, \mathrm{MeOH})$.

(+)-[2-[4,5-Difluoro-2-(2-fluoroethoxy)phenyl]cyclopropyl]methanamine Hydrochloride ((+)-21a). White solid. HPLC: 99.5\%; ${ }^{1} \mathrm{H}$ NMR $\left(\mathrm{CD}_{3} \mathrm{OD}\right) \delta 6.99-6.93(\mathrm{~m}, 2 \mathrm{H}), 4.88-4.74(\mathrm{~m}, 2 \mathrm{H}), 4.32-$ $4.22(\mathrm{~m}, 2 \mathrm{H}), 3.03-3.00(\mathrm{~m}, 2 \mathrm{H}), 2.11-2.07(\mathrm{~m}, 1 \mathrm{H}), 1.24-1.15$ (m, 2H), 1.05-1.00 (m, 1H); HRMS calcd for $\mathrm{C}_{12} \mathrm{H}_{15} \mathrm{~F}_{3} \mathrm{NO}^{+}$ $\left([\mathrm{M}+\mathrm{H}]^{+}\right): 246.1100$, found: $246.1086 ;[\alpha]_{\mathrm{D}}{ }^{20}+1.4(c 0.1, \mathrm{MeOH})$.

(-)-[2-[2,3-Difluoro-6-(2-fluoroethoxy)phenyl]cyclopropyl]methanamine Hydrochloride ((-)-21b). White solid. HPLC: 99.6\%; ${ }^{1} \mathrm{H}$ NMR $\left(\mathrm{CD}_{3} \mathrm{OD}\right) \delta 7.09(\mathrm{q}, J=9.6 \mathrm{~Hz}, 1 \mathrm{H}), 6.77-6.73(\mathrm{~m}, 1 \mathrm{H})$, $4.88-4.86(\mathrm{~m}, 1 \mathrm{H}), 4.77-4.74(\mathrm{~m}, 1 \mathrm{H}), 4.31-4.20(\mathrm{~m}, 2 \mathrm{H}), 3.10(\mathrm{dd}$, $J=13.2,7.6 \mathrm{~Hz}, 1 \mathrm{H}), 2.99(\mathrm{dd}, J=13.2,7.6 \mathrm{~Hz}, 1 \mathrm{H}), 1.89-1.84(\mathrm{~m}$, $1 \mathrm{H}), 1.56-1.53(\mathrm{~m}, 1 \mathrm{H}), 1.35-1.31(\mathrm{~m}, 1 \mathrm{H}), 1.12-1.07(\mathrm{~m}, 1 \mathrm{H}) ;{ }^{13} \mathrm{C}$ $\operatorname{NMR}\left(\mathrm{CD}_{3} \mathrm{OD}\right) \delta 155.6\left(\mathrm{dd}, J_{\mathrm{CF}}=5.6,2.1 \mathrm{~Hz}\right), 151.4\left(\mathrm{dd}, J_{\mathrm{CF}}=243.7\right.$, $13.9 \mathrm{~Hz}), 147.0\left(\mathrm{dd}, J_{\mathrm{CF}}=238.0,13.8 \mathrm{~Hz}\right), 119.9\left(\mathrm{~d}, J_{\mathrm{CF}}=11.5 \mathrm{~Hz}\right)$, $115.6\left(\mathrm{~d}, J_{\mathrm{CF}}=18.3 \mathrm{~Hz}\right), 108.2\left(\mathrm{dd}, J_{\mathrm{CF}}=3.6 \mathrm{~Hz}\right), 83.4\left(\mathrm{~d}, J_{\mathrm{CF}}=167.1\right.$ $\mathrm{Hz}), 69.7\left(\mathrm{~d}, J_{\mathrm{CF}}=18.9 \mathrm{~Hz}\right), 45.2,18.4,13.8,12.9$; HRMS calcd for $\mathrm{C}_{12} \mathrm{H}_{15} \mathrm{~F}_{3} \mathrm{NO}^{+}\left([\mathrm{M}+\mathrm{H}]^{+}\right): 246.1100$, found: $246.1099 ;[\alpha]_{\mathrm{D}}{ }^{20}-36.0(c$ $0.5, \mathrm{MeOH})$.

(+)-[2-[2,3-Difluoro-6-(2-fluoroethoxy)phenyl]cyclopropyl]methanamine Hydrochloride ((+)-21b). White solid. HPLC: 99.3\%; ${ }^{1} \mathrm{H}$ NMR $\left(\mathrm{CD}_{3} \mathrm{OD}\right) \delta 7.09(\mathrm{q}, J=9.6 \mathrm{~Hz}, 1 \mathrm{H}), 6.77-6.73(\mathrm{~m}, 1 \mathrm{H})$, $4.88-4.85(\mathrm{~m}, 1 \mathrm{H}), 4.76-4.74(\mathrm{~m}, 1 \mathrm{H}), 4.31-4.20(\mathrm{~m}, 2 \mathrm{H}), 3.09(\mathrm{dd}$, $J=13.2,7.6 \mathrm{~Hz}, 1 \mathrm{H}), 2.99(\mathrm{dd}, J=12.8,7.6 \mathrm{~Hz}, 1 \mathrm{H}), 1.89-1.84(\mathrm{~m}$, $1 \mathrm{H}), 1.56-1.53(\mathrm{~m}, 1 \mathrm{H}), 1.35-1.31(\mathrm{~m}, 1 \mathrm{H}), 1.12-1.07(\mathrm{~m}, 1 \mathrm{H})$; HRMS calcd for $\mathrm{C}_{12} \mathrm{H}_{15} \mathrm{~F}_{3} \mathrm{NO}^{+}\left([\mathrm{M}+\mathrm{H}]^{+}\right): 246.1100$, found: 246.1088; $[\alpha]_{\mathrm{D}}{ }^{20}+30.2($ c $0.2, \mathrm{MeOH})$.

(-)-[2-[5-Chloro-4-fluoro-2-(2-fluoroethoxy)phenyl]cyclopropyl]methanamine Hydrochloride ((-)-21c). White solid. HPLC: 99.2\%; ${ }^{1} \mathrm{H}$ NMR $\left(\mathrm{CD}_{3} \mathrm{OD}\right) \delta 7.10(\mathrm{~d}, J=8.0 \mathrm{~Hz}, 1 \mathrm{H}), 6.96(\mathrm{~d}, J=11.2 \mathrm{~Hz}, 1 \mathrm{H})$, $4.86-4.76(\mathrm{~m}, 2 \mathrm{H}), 4.35-4.24(\mathrm{~m}, 2 \mathrm{H}), 3.05-2.97(\mathrm{~m}, 2 \mathrm{H}), 2.10-2.04$ $(\mathrm{m}, 1 \mathrm{H}), 1.26-1.15(\mathrm{~m}, 2 \mathrm{H}), 1.05-1.00(\mathrm{~m}, 1 \mathrm{H}) ;{ }^{13} \mathrm{C} \mathrm{NMR}\left(\mathrm{CD}_{3} \mathrm{OD}\right)$ $\delta 158.6,158.5\left(\mathrm{~d}, J_{\mathrm{CF}}=244.2 \mathrm{~Hz}\right), 129.5,128.3,112.7\left(\mathrm{~d}, J_{\mathrm{CF}}=17.8 \mathrm{~Hz}\right)$, $102.3\left(\mathrm{~d}, J_{\mathrm{CF}}=25.4 \mathrm{~Hz}\right), 83.3\left(\mathrm{~d}, J_{\mathrm{CF}}=167.0 \mathrm{~Hz}\right), 69.7\left(\mathrm{~d}, J_{\mathrm{CF}}=\right.$ $18.8 \mathrm{~Hz}), 45.0,19.5,17.8,12.6$; HRMS calcd for $\mathrm{C}_{12} \mathrm{H}_{15} \mathrm{ClF}_{2} \mathrm{NO}^{+}$ $\left([\mathrm{M}+\mathrm{H}]^{+}\right): 262.0805$, found: $262.0782 ;[\alpha]_{\mathrm{D}}{ }^{20}-26.4(c 0.5, \mathrm{MeOH})$.

(+)-[2-[5-Chloro-4-fluoro-2-(2-fluoroethoxy)phenyl]cyclopropyl]methanamine Hydrochloride ((+)-21c). White solid. HPLC: 99.3\%; ${ }^{1} \mathrm{H} \mathrm{NMR}\left(\mathrm{CD}_{3} \mathrm{OD}\right) \delta 7.10(\mathrm{~d}, J=8.4 \mathrm{~Hz}, 1 \mathrm{H}), 6.96(\mathrm{~d}, J=10.8 \mathrm{~Hz}, 1 \mathrm{H})$, $4.86-4.75(\mathrm{~m}, 2 \mathrm{H}), 4.34-4.24(\mathrm{~m}, 2 \mathrm{H}), 3.04-2.98(\mathrm{~m}, 2 \mathrm{H}), 2.09-2.04$ $(\mathrm{m}, 1 \mathrm{H}), 1.25-1.15(\mathrm{~m}, 2 \mathrm{H}), 1.05-1.00(\mathrm{~m}, 1 \mathrm{H}) ;{ }^{13} \mathrm{C} \mathrm{NMR}\left(\mathrm{CD}_{3} \mathrm{OD}\right)$ $\delta 158.6,158.5\left(\mathrm{~d}, J_{\mathrm{CF}}=243.9 \mathrm{~Hz}\right), 129.5,128.3,112.7\left(\mathrm{~d}, J_{\mathrm{CF}}=17.5 \mathrm{~Hz}\right)$, $102.3\left(\mathrm{~d}, J_{\mathrm{CF}}=25.5 \mathrm{~Hz}\right), 83.3\left(\mathrm{~d}, J_{\mathrm{CF}}=167.1 \mathrm{~Hz}\right), 69.7\left(\mathrm{~d}, J_{\mathrm{CF}}=\right.$ $19.0 \mathrm{~Hz}), 45.0,19.5,17.8,12.6$; HRMS calcd for $\mathrm{C}_{12} \mathrm{H}_{15} \mathrm{ClF}_{2} \mathrm{NO}^{+}([\mathrm{M}+$ $\left.\mathrm{H}]^{+}\right): 262.0805$, found: $262.0788 ;[\alpha]_{\mathrm{D}}{ }^{20}+28.4(c 0.5, \mathrm{MeOH})$.

(-)-[2-[3-Chloro-2-fluoro-6-(2-fluoroethoxy)phenyl]cyclopropyl]methanamine Hydrochloride ((-)-21d). White solid. HPLC: 98.8\%; ${ }^{1} \mathrm{H} \mathrm{NMR}\left(\mathrm{CD}_{3} \mathrm{OD}\right) \delta 7.29(\mathrm{t}, J=8.8 \mathrm{~Hz}, 1 \mathrm{H}), 6.81(\mathrm{~d}, J=9.2 \mathrm{~Hz}, 1 \mathrm{H})$, $4.88-4.83(\mathrm{~m}, 1 \mathrm{H}), 4.77-4.75(\mathrm{~m}, 1 \mathrm{H}), 4.35-4.21(\mathrm{~m}, 2 \mathrm{H}), 3.09(\mathrm{dd}$, $J=13.2,7.2 \mathrm{~Hz}, 1 \mathrm{H}), 2.98(\mathrm{dd}, J=13.2,7.6 \mathrm{~Hz}, 1 \mathrm{H}), 1.88-1.83(\mathrm{~m}$, $1 \mathrm{H}), 1.55-1.51(\mathrm{~m}, 1 \mathrm{H}), 1.32-1.28(\mathrm{~m}, 1 \mathrm{H}), 1.12-1.06(\mathrm{~m}, 1 \mathrm{H}) ;{ }^{13} \mathrm{C}$ $\operatorname{NMR}\left(\mathrm{CD}_{3} \mathrm{OD}\right) \delta 159.0\left(\mathrm{~d}, J_{\mathrm{CF}}=6.4 \mathrm{~Hz}\right), 158.7\left(\mathrm{~d}, J_{\mathrm{CF}}=244.0 \mathrm{~Hz}\right)$, $129.5,119.4\left(\mathrm{~d}, J_{\mathrm{CF}}=14.7 \mathrm{~Hz}\right), 114.4\left(\mathrm{~d}, J_{\mathrm{CF}}=19.2 \mathrm{~Hz}\right), 109.5,83.3(\mathrm{~d}$, $\left.J_{\mathrm{CF}}=167.4 \mathrm{~Hz}\right), 69.6\left(\mathrm{~d}, J_{\mathrm{CF}}=19.0 \mathrm{~Hz}\right), 45.3,18.5,13.9,13.1$; HRMS calcd for $\mathrm{C}_{12} \mathrm{H}_{15} \mathrm{ClF}_{2} \mathrm{NO}^{+}\left([\mathrm{M}+\mathrm{H}]^{+}\right)$: 262.0805, found: 262.0791; $[\alpha]_{\mathrm{D}}{ }^{20}-53.0(c 0.3, \mathrm{MeOH})$.

(+)-[2-[3-Chloro-2-fluoro-6-(2-fluoroethoxy)phenyl]cyclopropyl]methanamine Hydrochloride ((+)-21d). White solid. HPLC: $99.3 \%$; ${ }^{1} \mathrm{H}$ NMR $\left(\mathrm{CD}_{3} \mathrm{OD}\right) \delta 7.29(\mathrm{t}, J=8.8 \mathrm{~Hz}, 1 \mathrm{H}), 6.81(\mathrm{dd}, J=8.8,1.4 \mathrm{~Hz}$, $1 \mathrm{H}), 4.88-4.83(\mathrm{~m}, 1 \mathrm{H}), 4.77-4.74(\mathrm{~m}, 1 \mathrm{H}), 4.33-4.23(\mathrm{~m}, 2 \mathrm{H}), 3.10$ $(\mathrm{dd}, J=12.8,7.2 \mathrm{~Hz}, 1 \mathrm{H}), 2.98(\mathrm{dd}, J=13.2,7.6 \mathrm{~Hz}, 1 \mathrm{H}), 1.88-1.83(\mathrm{~m}$, $1 \mathrm{H}), 1.55-1.51(\mathrm{~m}, 1 \mathrm{H}), 1.32-1.28(\mathrm{~m}, 1 \mathrm{H}), 1.12-1.06(\mathrm{~m}, 1 \mathrm{H}) ;{ }^{13} \mathrm{C}$ $\operatorname{NMR}\left(\mathrm{CD}_{3} \mathrm{OD}\right) \delta 159.0\left(\mathrm{~d}, J_{\mathrm{CF}}=6.5 \mathrm{~Hz}\right), 158.7\left(\mathrm{~d}, J_{\mathrm{CF}}=244.4 \mathrm{~Hz}\right)$, $129.5,119.4\left(\mathrm{~d}, J_{\mathrm{CF}}=14.7 \mathrm{~Hz}\right), 114.4\left(\mathrm{~d}, J_{\mathrm{CF}}=19.3 \mathrm{~Hz}\right), 109.5,83.3(\mathrm{~d}$, $\left.J_{\mathrm{CF}}=167.3 \mathrm{~Hz}\right), 69.6\left(\mathrm{~d}, J_{\mathrm{CF}}=19.0 \mathrm{~Hz}\right), 45.3,18.5,13.9,13.1 ; \mathrm{HRMS}$ calcd for $\mathrm{C}_{12} \mathrm{H}_{15} \mathrm{ClF}_{2} \mathrm{NO}^{+}\left([\mathrm{M}+\mathrm{H}]^{+}\right)$: 262.0805, found: 246.0793; $[\alpha]_{\mathrm{D}}{ }^{20}+53.5(c 0.4, \mathrm{MeOH})$

(-)-[2-[4,5-Dichloro-2-(2-fluoroethoxy)phenyl]cyclopropyl]methanamine Hydrochloride ((-)-21e). White solid. HPLC: 99.6\%; ${ }^{1} \mathrm{H}$ NMR $\left(\mathrm{CD}_{3} \mathrm{OD}\right) \delta 7.16(\mathrm{~s}, 1 \mathrm{H}), 7.15(\mathrm{~s}, 1 \mathrm{H}), 4.88-4.74(\mathrm{~m}, 2 \mathrm{H})$, $4.37-4.25(\mathrm{~m}, 2 \mathrm{H}), 3.04-3.02(\mathrm{~m}, 2 \mathrm{H}), 2.13-2.08(\mathrm{~m}, 1 \mathrm{H}), 1.29-1.25$ $(\mathrm{m}, 1 \mathrm{H}), 1.23-1.18(\mathrm{~m}, 1 \mathrm{H}), 1.08-1.01(\mathrm{~m}, 1 \mathrm{H})$; HRMS calcd for $\mathrm{C}_{12} \mathrm{H}_{15} \mathrm{Cl}_{2} \mathrm{FNO}^{+}\left([\mathrm{M}+\mathrm{H}]^{+}\right): 278.0509$, found: 278.0496; $[\alpha]_{\mathrm{D}}{ }^{20}-32.4$ (c $0.25, \mathrm{MeOH})$. 
(+)-[2-[4,5-Dichloro-2-(2-fluoroethoxy)phenyl]cyclopropyl]methanamine Hydrochloride ((+)-21e). White solid. HPLC: 99.4\%; ${ }^{1} \mathrm{H}$ NMR $\left(\mathrm{CD}_{3} \mathrm{OD}\right) \delta 7.16(\mathrm{~s}, 1 \mathrm{H}), 7.15(\mathrm{~s}, 1 \mathrm{H}), 4.88-4.75(\mathrm{~m}, 2 \mathrm{H})$, $4.36-4.24(\mathrm{~m}, 2 \mathrm{H}), 3.04-3.01(\mathrm{~m}, 2 \mathrm{H}), 2.13-2.08(\mathrm{~m}, 1 \mathrm{H}), 1.29-1.26$ (m, $1 \mathrm{H}), 1.23-1.19(\mathrm{~m}, 1 \mathrm{H}), 1.08-1.03(\mathrm{~m}, 1 \mathrm{H}) ;{ }^{13} \mathrm{C} \mathrm{NMR}\left(\mathrm{CD}_{3} \mathrm{OD}\right)$ $\delta 158.1,131.9,131.6,129.5,125.1,114.8,83.3\left(\mathrm{~d}, J_{\mathrm{CF}}=167.1 \mathrm{~Hz}\right), 69.7$ $\left(\mathrm{d}, J_{\mathrm{CF}}=18.9 \mathrm{~Hz}\right), 44.9,19.7,17.9,12.9$; $\mathrm{HRMS}$ calcd for $\mathrm{C}_{12} \mathrm{H}_{15} \mathrm{Cl}_{2} \mathrm{FNO}^{+}$ $\left([\mathrm{M}+\mathrm{H}]^{+}\right): 278.0509$, found: $278.0508 ;[\alpha]_{\mathrm{D}}{ }^{20}+30.2(c 0.5, \mathrm{MeOH})$.

(-)-[2-[2,3-Dichloro-6-(2-fluoroethoxy)phenyl]cyclopropyl]methanamine Hydrochloride ((-)-21f). White solid. HPLC: 99.3\%; ${ }^{1} \mathrm{H}$ NMR (DMSO- $\left.d_{6}\right) \delta 8.09(\mathrm{br}, 3 \mathrm{H}), 7.48(\mathrm{~d}, J=8.8 \mathrm{~Hz}, 1 \mathrm{H}), 7.03(\mathrm{~d}$, $J=8.8 \mathrm{~Hz}, 1 \mathrm{H}), 4.90-4.73(\mathrm{~m}, 2 \mathrm{H}), 4.32-4.22(\mathrm{~m}, 2 \mathrm{H}), 3.26-3.22(\mathrm{~m}$, $1 \mathrm{H}), 2.64-2.59(\mathrm{~m}, 1 \mathrm{H}), 1.78-1.73(\mathrm{~m}, 1 \mathrm{H}), 1.45-1.41(\mathrm{~m}, 1 \mathrm{H})$, $1.18-1.12(\mathrm{~m}, 1 \mathrm{H}), 1.04-1.00(\mathrm{~m}, 1 \mathrm{H}) ;{ }^{13} \mathrm{C}$ NMR (DMSO- $\left.d_{6}\right) \delta 157.1$, $133.8,128.8,128.6,123.5,112.4,82.2\left(\mathrm{~d}, J_{\mathrm{CF}}=165.6 \mathrm{~Hz}\right), 68.1\left(\mathrm{~d}, J_{\mathrm{CF}}=\right.$ $18.6 \mathrm{~Hz}), 42.7,18.7,16.9,14.0$; HRMS calcd for $\mathrm{C}_{12} \mathrm{H}_{15} \mathrm{Cl}_{2} \mathrm{FNO}^{+}([\mathrm{M}+$ $\left.\mathrm{H}]^{+}\right): 278.0509$, found: 278.0494; $[\alpha]_{\mathrm{D}}{ }^{20}-96.0($ c $0.1, \mathrm{MeOH})$.

(+)-[2-[2,3-Dichloro-6-(2-fluoroethoxy)phenyl]cyclopropyl]methanamine Hydrochloride ((+)-21f). White solid. HPLC: $99.0 \% ;{ }^{1} \mathrm{H}$ NMR (DMSO- $\left.d_{6}\right) \delta 8.11(\mathrm{br}, 3 \mathrm{H}), 7.47(\mathrm{~d}, J=8.8 \mathrm{~Hz}, 1 \mathrm{H}), 7.03(\mathrm{~d}, J=$ $8.8 \mathrm{~Hz}, 1 \mathrm{H}), 4.89-4.73(\mathrm{~m}, 2 \mathrm{H}), 4.32-4.22(\mathrm{~m}, 2 \mathrm{H}), 3.24(\mathrm{dd}, J=12.4$, $5.2 \mathrm{~Hz}, 1 \mathrm{H}), 2.64-2.59(\mathrm{~m}, 1 \mathrm{H}), 1.78-1.73(\mathrm{~m}, 1 \mathrm{H}), 1.45-1.41(\mathrm{~m}$, $1 \mathrm{H}), 1.18-1.13(\mathrm{~m}, 1 \mathrm{H}), 1.04-1.00(\mathrm{~m}, 1 \mathrm{H}) ;{ }^{13} \mathrm{C}$ NMR (DMSO- $\left.d_{6}\right) \delta$ $157.0,133.7,128.8,128.6,123.5,112.4,82.2\left(\mathrm{~d}, J_{\mathrm{CF}}=165.6 \mathrm{~Hz}\right), 68.1(\mathrm{~d}$, $\left.J_{\mathrm{CF}}=18.6 \mathrm{~Hz}\right), 42.7,18.6,16.9,13.9$; HRMS calcd for $\mathrm{C}_{12} \mathrm{H}_{15} \mathrm{Cl}_{2} \mathrm{FNO}^{+}$ $\left([\mathrm{M}+\mathrm{H}]^{+}\right): 278.0509$, found: $278.0493 ;[\alpha]_{\mathrm{D}}{ }^{20}+70.0(c 0.1, \mathrm{MeOH})$. (-)-[2-[2-Chloro-3-fluoro-6-(2-fluoroethoxy)phenyl]cyclopropyl]methanamine Hydrochloride ((-)-21g). White solid. HPLC: 99.1\%; ${ }^{1} \mathrm{H}$ NMR $\left(\mathrm{CD}_{3} \mathrm{OD}\right) \delta 7.11(\mathrm{t}, J=8.8 \mathrm{~Hz}, 1 \mathrm{H}), 6.94(\mathrm{dd}, J=9.0,4.2 \mathrm{~Hz}$, $1 \mathrm{H}), 4.88-4.85(\mathrm{~m}, 1 \mathrm{H}), 4.77-4.74(\mathrm{~m}, 1 \mathrm{H}), 4.32-4.20(\mathrm{~m}, 2 \mathrm{H}), 3.34$ $(\mathrm{dd}, J=13.2,6.4 \mathrm{~Hz}, 1 \mathrm{H}), 2.85(\mathrm{dd}, J=13.2,8.8 \mathrm{~Hz}, 1 \mathrm{H}), 1.85-1.79(\mathrm{~m}$, $1 \mathrm{H}), 1.56-1.50(\mathrm{~m}, 1 \mathrm{H}), 1.23-1.18(\mathrm{~m}, 2 \mathrm{H}) ;{ }^{13} \mathrm{C} \mathrm{NMR}\left(\mathrm{CD}_{3} \mathrm{OD}\right) \delta$ 156.0, $154.5\left(\mathrm{~d}, J_{\mathrm{CF}}=238.6 \mathrm{~Hz}\right), 129.7,124.7\left(\mathrm{~d}, J_{\mathrm{CF}}=18.2 \mathrm{~Hz}\right), 115.5$ $\left(\mathrm{d}, J_{\mathrm{CF}}=22.9 \mathrm{~Hz}\right), 112.6\left(\mathrm{~d}, J_{\mathrm{CF}}=7.6 \mathrm{~Hz}\right), 83.4\left(\mathrm{~d}, J_{\mathrm{CF}}=167.3 \mathrm{~Hz}\right), 69.8$ $\left(\mathrm{d}, J_{\mathrm{CF}}=18.9 \mathrm{~Hz}\right), 45.3,19.7,17.7,14.7$; HRMS calcd for $\mathrm{C}_{12} \mathrm{H}_{15} \mathrm{ClF}_{2} \mathrm{NO}^{+}\left([\mathrm{M}+\mathrm{H}]^{+}\right): 262.0805$, found: 262.0801; $[\alpha]_{\mathrm{D}}{ }^{20}$ -54.5 (c 0.2, $\mathrm{MeOH})$.

(+)-[2-[2-Chloro-3-fluoro-6-(2-fluoroethoxy)phenyl]cyclopropyl]methanamine Hydrochloride ((+)-21g). White solid. HPLC: 99.2\%; ${ }^{1} \mathrm{H}$ NMR $\left(\mathrm{CD}_{3} \mathrm{OD}\right) \delta 7.11(\mathrm{t}, J=8.8 \mathrm{~Hz}, 1 \mathrm{H}), 6.94(\mathrm{dd}, J=9.0,4.2 \mathrm{~Hz}$, $1 \mathrm{H}), 4.88-4.85(\mathrm{~m}, 1 \mathrm{H}), 4.78-4.74(\mathrm{~m}, 1 \mathrm{H}), 4.33-4.20(\mathrm{~m}, 2 \mathrm{H}), 3.34$ $(\mathrm{dd}, J=13.2,8.8 \mathrm{~Hz}, 1 \mathrm{H}), 2.85(\mathrm{dd}, J=13.2,8.8 \mathrm{~Hz}, 1 \mathrm{H}), 1.85-1.79(\mathrm{~m}$, $1 \mathrm{H}), 1.56-1.52(\mathrm{~m}, 1 \mathrm{H}), 1.24-1.17(\mathrm{~m}, 2 \mathrm{H}) ;{ }^{13} \mathrm{C} \mathrm{NMR}\left(\mathrm{CD}_{3} \mathrm{OD}\right) \delta$ 156.0, 154.5 (d, $\left.J_{\mathrm{CF}}=238.6 \mathrm{~Hz}\right), 129.7,124.7\left(\mathrm{~d}, J_{\mathrm{CF}}=18.2 \mathrm{~Hz}\right), 115.5$ $\left(\mathrm{d}, J_{\mathrm{CF}}=22.8 \mathrm{~Hz}\right), 112.6\left(\mathrm{~d}, J_{\mathrm{CF}}=7.7 \mathrm{~Hz}\right), 83.4\left(\mathrm{~d}, J_{\mathrm{CF}}=167.3 \mathrm{~Hz}\right), 69.8$ $\left(\mathrm{d}, J_{\mathrm{CF}}=19.0 \mathrm{~Hz}\right), 45.3,19.7,17.7,14.7$; HRMS calcd for $\mathrm{C}_{12} \mathrm{H}_{15} \mathrm{ClF}_{2} \mathrm{NO}^{+}\left([\mathrm{M}+\mathrm{H}]^{+}\right): 262.0805$, found: $262.0807 ;[\alpha]_{\mathrm{D}}{ }^{20}$ $+61.4(c 0.3, \mathrm{MeOH})$.

(-)-[2-[2-(Allyloxy)-4,5-difluorophenyl]cyclopropyl]methanamine Hydrochloride ((-)-22a). White solid. HPLC: 99.3\%; ${ }^{1} \mathrm{H}$ NMR $\left(\mathrm{CD}_{3} \mathrm{OD}\right) \delta 6.95-6.88(\mathrm{~m}, 2 \mathrm{H}), 6.18-6.08(\mathrm{~m}, 1 \mathrm{H}), 5.47(\mathrm{dd}, J=$ $17.2,1.6 \mathrm{~Hz}, 1 \mathrm{H}), 5.33(\mathrm{dd}, J=10.4,1.6 \mathrm{~Hz}, 1 \mathrm{H}), 4.60(\mathrm{~d}, J=5.2 \mathrm{~Hz}$, $2 \mathrm{H}), 3.07(\mathrm{dd}, J=12.8,7.2 \mathrm{~Hz}, 1 \mathrm{H}), 2.98(\mathrm{dd}, J=13.2,8.0 \mathrm{~Hz}, 1 \mathrm{H})$, 2.17-2.09 (m, 1H), 1.33-1.29 (m, 1H), 1.13-1.02 (m, 2H); ${ }^{13} \mathrm{C}$ NMR $\left(\mathrm{CD}_{3} \mathrm{OD}\right) \delta 155.0\left(\mathrm{dd}, J_{\mathrm{CF}}=7.6,2.0 \mathrm{~Hz}\right), 150.0\left(\mathrm{dd}, J_{\mathrm{CF}}=242.8\right.$, $13.5 \mathrm{~Hz}), 145.7\left(\mathrm{dd}, J_{\mathrm{CF}}=236.9,12.7 \mathrm{~Hz}\right), 134.5,127.5,118.6,116.2(\mathrm{~d}$, $\left.J_{\mathrm{CF}}=19.2 \mathrm{~Hz}\right), 103.1\left(\mathrm{~d}, J_{\mathrm{CF}}=21.3 \mathrm{~Hz}\right), 71.1,45.1,19.4,18.0,13.4$; HRMS calcd for $\mathrm{C}_{13} \mathrm{H}_{16} \mathrm{~F}_{2} \mathrm{NO}^{+}\left([\mathrm{M}+\mathrm{H}]^{+}\right)$: 240.1194, found: 240.1189; $[\alpha]_{\mathrm{D}}{ }^{20}-14.0$ (c 0.4, $\left.\mathrm{MeOH}\right)$.

(+)-[2-[2-(Allyloxy)-4,5-difluorophenyl]cyclopropyl]methanamine Hydrochloride ((+)-22a). White solid. HPLC: 99.4\%; ${ }^{1} \mathrm{H}$ NMR $\left(\mathrm{CD}_{3} \mathrm{OD}\right) \delta 6.94-6.89(\mathrm{~m}, 2 \mathrm{H}), 6.18-6.08(\mathrm{~m}, 1 \mathrm{H}), 5.47(\mathrm{dd}, J=$ $17.2,1.6 \mathrm{~Hz}, 1 \mathrm{H}), 5.33(\mathrm{dd}, J=10.8,1.6 \mathrm{~Hz}, 1 \mathrm{H}), 4.60(\mathrm{~d}, J=5.2 \mathrm{~Hz}, 2 \mathrm{H})$, $3.06(\mathrm{dd}, J=13.2,7.2 \mathrm{~Hz}, 1 \mathrm{H}), 2.97(\mathrm{dd}, J=13.2,7.6 \mathrm{~Hz}, 1 \mathrm{H}), 2.17-2.08$ (m, $1 \mathrm{H}), 1.33-1.28(\mathrm{~m}, 1 \mathrm{H}), 1.13-1.02(\mathrm{~m}, 2 \mathrm{H})$; HRMS calcd for $\mathrm{C}_{13} \mathrm{H}_{16} \mathrm{~F}_{2} \mathrm{NO}^{+}\left([\mathrm{M}+\mathrm{H}]^{+}\right): 240.1194$, found: $246.1192 ;[\alpha]_{\mathrm{D}}{ }^{20}+12.0$ (c $0.1, \mathrm{MeOH})$.

(-)-[2-[6-(Allyloxy)-2,3-difluorophenyl]cyclopropyl]methanamine Hydrochloride ((-)-22b). White solid. HPLC: 97.0\%; ${ }^{1} \mathrm{H}$ NMR $\left(\mathrm{CD}_{3} \mathrm{OD}\right) \delta 7.06(\mathrm{q}, J=9.6 \mathrm{~Hz}, 1 \mathrm{H}), 6.75-6.71(\mathrm{~m}, 1 \mathrm{H}), 6.16-6.09$ $(\mathrm{m}, 1 \mathrm{H}), 5.46(\mathrm{dd}, J=17.2,1.6 \mathrm{~Hz}, 1 \mathrm{H}), 5.32(\mathrm{dd}, J=10.8,1.6 \mathrm{~Hz}, 1 \mathrm{H})$, $4.59(\mathrm{~d}, J=5.6 \mathrm{~Hz}, 2 \mathrm{H}), 3.08(\mathrm{dd}, J=13.2,7.6 \mathrm{~Hz}, 1 \mathrm{H}), 3.01(\mathrm{dd}, J=$ $13.2,7.6 \mathrm{~Hz}, 1 \mathrm{H}), 1.91-1.86(\mathrm{~m}, 1 \mathrm{H}), 1.61-1.56(\mathrm{~m}, 1 \mathrm{H}), 1.31-1.27$ $(\mathrm{m}, 1 \mathrm{H}), 1.12-1.08(\mathrm{~m}, 1 \mathrm{H}) ;{ }^{13} \mathrm{C} \mathrm{NMR}\left(\mathrm{CD}_{3} \mathrm{OD}\right) \delta 155.7\left(\mathrm{~d}, J_{\mathrm{CF}}=\right.$ $5.6 \mathrm{~Hz}), 151.3\left(\mathrm{dd}, J_{\mathrm{CF}}=243.3,14.0 \mathrm{~Hz}\right), 146.8\left(\mathrm{dd}, J_{\mathrm{CF}}=237.6\right.$, $13.8 \mathrm{~Hz}), 134.6,119.7\left(\mathrm{~d}, J_{\mathrm{CF}}=11.2 \mathrm{~Hz}\right), 118.6,115.5\left(\mathrm{~d}, J_{\mathrm{CF}}=18.3 \mathrm{~Hz}\right)$, 108.5, 71.1, 45.3, 18.3, 13.9, 13.0; HRMS calcd for $\mathrm{C}_{13} \mathrm{H}_{16} \mathrm{~F}_{2} \mathrm{NO}^{+}([\mathrm{M}+$ $\left.\mathrm{H}]^{+}\right): 240.1194$, found: $240.1188 ;[\alpha]_{\mathrm{D}}{ }^{20}-46.8($ c $0.5, \mathrm{MeOH})$.

(+)-[2-[6-(Allyloxy)-2,3-difluorophenyl]cyclopropyl]methanamine Hydrochloride $((+)-22 b)$. White solid. HPLC: 99.7\%; ${ }^{1} \mathrm{H}$ NMR $\left(\mathrm{CD}_{3} \mathrm{OD}\right) \delta 7.06(\mathrm{q}, J=9.6 \mathrm{~Hz}, 1 \mathrm{H}), 6.75-6.71(\mathrm{~m}, 1 \mathrm{H}), 6.16-6.08$ $(\mathrm{m}, 1 \mathrm{H}), 5.46(\mathrm{dd}, J=17.2,1.6 \mathrm{~Hz}, 1 \mathrm{H}), 5.32(\mathrm{dd}, J=10.4,1.6 \mathrm{~Hz}, 1 \mathrm{H})$, $4.59(\mathrm{~d}, J=5.6 \mathrm{~Hz}, 2 \mathrm{H}), 3.07(\mathrm{dd}, J=13.2,7.6 \mathrm{~Hz}, 1 \mathrm{H}), 3.00(\mathrm{dd}, J=$ $13.2,7.6 \mathrm{~Hz}, 1 \mathrm{H}), 1.91-1.85(\mathrm{~m}, 1 \mathrm{H}), 1.60-1.56(\mathrm{~m}, 1 \mathrm{H}), 1.31-1.26$ (m, 1H), 1.11-1.06 (m, 1H); HRMS calcd for $\mathrm{C}_{13} \mathrm{H}_{16} \mathrm{~F}_{2} \mathrm{NO}^{+}([\mathrm{M}+$ $\mathrm{H}]^{+}$): 240.1194, found: $240.1191 ;[\alpha]_{\mathrm{D}}{ }^{20}+41.6($ c $0.2, \mathrm{MeOH})$.

(-)-[2-[2-(Allyloxy)-5-chloro-4-fluorophenyl]cyclopropyl]methanamine Hydrochloride ((-)-22c). White solid. HPLC: 99.8\%; ${ }^{1} \mathrm{H} \mathrm{NMR}\left(\mathrm{CD}_{3} \mathrm{OD}\right) \delta 7.07(\mathrm{~d}, J=8.4 \mathrm{~Hz}, 1 \mathrm{H}), 6.90(\mathrm{~d}, J=11.2 \mathrm{~Hz}, 1 \mathrm{H})$, 6.18-6.08 (m, 1H), $5.47(\mathrm{dd}, J=13.6,1.6 \mathrm{~Hz}, 1 \mathrm{H}), 5.34(\mathrm{dd}, J=10.4$, $1.6 \mathrm{~Hz}, 1 \mathrm{H}), 4.62(\mathrm{~d}, J=5.2 \mathrm{~Hz}, 2 \mathrm{H}), 3.06(\mathrm{dd}, J=12.8,7.2 \mathrm{~Hz}, 1 \mathrm{H})$, $2.98(\mathrm{dd}, J=12.8,8.0 \mathrm{~Hz}, 1 \mathrm{H}), 2.11-2.05(\mathrm{~m}, 1 \mathrm{H}), 1.32-1.28(\mathrm{~m}, 1 \mathrm{H})$, $1.13-1.01(\mathrm{~m}, 2 \mathrm{H}) ;{ }^{13} \mathrm{C} \mathrm{NMR}\left(\mathrm{CD}_{3} \mathrm{OD}\right) \delta 158.5,158.4\left(\mathrm{~d}, J_{\mathrm{CF}}=\right.$ $243.8 \mathrm{~Hz}), 134.3,129.2,128.3,118.8,112.3\left(\mathrm{~d}, J_{\mathrm{CF}}=17.6 \mathrm{~Hz}\right), 102.4(\mathrm{~d}$, $J_{\mathrm{CF}}=25.4 \mathrm{~Hz}$ ), 70.9, 45.0, 19.2, 17.9, 13.2; HRMS (ESI) $\mathrm{m} / z$ calcd for $\mathrm{C}_{13} \mathrm{H}_{16} \mathrm{ClFNO}^{+}\left([\mathrm{M}+\mathrm{H}]^{+}\right): 256.0899$, found: $256.0875 ;[\alpha]_{\mathrm{D}}{ }^{20}-36.2$ (c $0.5, \mathrm{MeOH})$.

(+)-[2-[2-(Allyloxy)-5-chloro-4-fluorophenyl]cyclopropyl]methanamine Hydrochloride ((+)-22c). White solid. HPLC: 99.3\%; ${ }^{1} \mathrm{H} \mathrm{NMR}\left(\mathrm{CD}_{3} \mathrm{OD}\right) \delta 7.07(\mathrm{~d}, J=8.4 \mathrm{~Hz}, 1 \mathrm{H}), 6.91(\mathrm{~d}, J=11.2 \mathrm{~Hz}, 1 \mathrm{H})$, $6.17-6.08(\mathrm{~m}, 1 \mathrm{H}), 5.47(\mathrm{dd}, J=13.6,1.6 \mathrm{~Hz}, 1 \mathrm{H}), 5.34(\mathrm{dd}, J=11.2$, $1.2 \mathrm{~Hz}, 1 \mathrm{H}), 4.62(\mathrm{~d}, J=5.2 \mathrm{~Hz}, 2 \mathrm{H}), 3.06(\mathrm{dd}, J=11.2,7.2 \mathrm{~Hz}, 1 \mathrm{H})$, $2.99(\mathrm{dd}, J=12.8,5.6 \mathrm{~Hz}, 1 \mathrm{H}), 2.11-2.05(\mathrm{~m}, 1 \mathrm{H}), 1.32-1.28(\mathrm{~m}, 1 \mathrm{H})$, $1.13-1.01(\mathrm{~m}, 2 \mathrm{H}) ;{ }^{13} \mathrm{C} \mathrm{NMR}\left(\mathrm{CD}_{3} \mathrm{OD}\right) \delta 158.5,158.4\left(\mathrm{~d}, J_{\mathrm{CF}}=\right.$ $243.7 \mathrm{~Hz}), 134.3,129.2,128.3,118.8,112.3\left(\mathrm{~d}, J_{\mathrm{CF}}=17.6 \mathrm{~Hz}\right), 102.4(\mathrm{~d}$, $J_{\mathrm{CF}}=25.4 \mathrm{~Hz}$ ), 70.9, 45.0, 19.2, 17.9, 13.2; HRMS (ESI) $\mathrm{m} / z$ calcd for $\mathrm{C}_{13} \mathrm{H}_{16} \mathrm{ClFNO}^{+}\left([\mathrm{M}+\mathrm{H}]^{+}\right): 256.0899$, found: $256.0880 ;[\alpha]_{\mathrm{D}}{ }^{20}+34.6$ (c $0.5, \mathrm{MeOH})$.

(-)-[2-[6-(Allyloxy)-3-chloro-2-fluorophenyl]cyclopropyl]methanamine Hydrochloride ((-)-22d). White solid. HPLC: 98.5\%; ${ }^{1} \mathrm{H} \mathrm{NMR}\left(\mathrm{CD}_{3} \mathrm{OD}\right) \delta 7.26(\mathrm{t}, J=8.4 \mathrm{~Hz}, 1 \mathrm{H}), 6.79(\mathrm{~d}, J=9.2 \mathrm{~Hz}, 1 \mathrm{H})$, 6.17-6.07 (m, 1H), $5.46(\mathrm{~d}, J=17.2 \mathrm{~Hz}, 1 \mathrm{H}), 5.33(\mathrm{~d}, J=10.4 \mathrm{~Hz}, 1 \mathrm{H})$, $4.61(\mathrm{~d}, J=5.2 \mathrm{~Hz}, 2 \mathrm{H}), 3.08-2.97(\mathrm{~m}, 2 \mathrm{H}), 1.88-1.83(\mathrm{~m}, 1 \mathrm{H}), 1.59-$ $1.52(\mathrm{~m}, 1 \mathrm{H}), 1.28-1.22(\mathrm{~m}, 1 \mathrm{H}), 1.11-1.06(\mathrm{~m}, 1 \mathrm{H}) ;{ }^{13} \mathrm{C}$ NMR $\left(\mathrm{CD}_{3} \mathrm{OD}\right) \delta 159.0\left(\mathrm{~d}, J_{\mathrm{CF}}=6.4 \mathrm{~Hz}\right), 158.7\left(\mathrm{~d}, J_{\mathrm{CF}}=243.9 \mathrm{~Hz}\right), 134.4$, $129.4,119.2\left(\mathrm{~d}, J_{\mathrm{CF}}=14.6 \mathrm{~Hz}\right), 118.7,113.9\left(\mathrm{~d}, J_{\mathrm{CF}}=19.3 \mathrm{~Hz}\right), 109.7$, 70.9, 45.3, 18.4, 13.9, 13.1; HRMS (ESI) $m / z$ calcd for $\mathrm{C}_{13} \mathrm{H}_{16} \mathrm{ClFNO}^{+}$ $\left([\mathrm{M}+\mathrm{H}]^{+}\right): 256.0899$, found: $256.0900 ;[\alpha]_{\mathrm{D}}{ }^{20}-54.0(c 0.3, \mathrm{MeOH})$.

(+)-[2-[6-(Allyloxy)-3-chloro-2-fluorophenyl]cyclopropyl]methanamine Hydrochloride ((+)-22d). White solid. HPLC: 99.6\%; ${ }^{1} \mathrm{H} \mathrm{NMR}\left(\mathrm{CD}_{3} \mathrm{OD}\right) \delta 7.26(\mathrm{t}, J=8.6 \mathrm{~Hz}, 1 \mathrm{H}), 6.79(\mathrm{dd}, J=9.2,1.6 \mathrm{~Hz}$, $1 \mathrm{H}), 6.17-6.07(\mathrm{~m}, 1 \mathrm{H}), 5.46(\mathrm{dd}, J=17.2,1.4 \mathrm{~Hz}, 1 \mathrm{H}), 5.33$ (dd, $J=$ $10.4,1.2 \mathrm{~Hz}, 1 \mathrm{H}), 4.61(\mathrm{~d}, J=5.6 \mathrm{~Hz}, 2 \mathrm{H}), 3.08-2.97(\mathrm{~m}, 2 \mathrm{H}), 1.88-$ $1.83(\mathrm{~m}, 1 \mathrm{H}), 1.57-1.52(\mathrm{~m}, 1 \mathrm{H}), 1.28-1.22(\mathrm{~m}, 1 \mathrm{H}), 1.11-1.06(\mathrm{~m}$, $1 \mathrm{H}) ;{ }^{13} \mathrm{C}$ NMR $\left(\mathrm{CD}_{3} \mathrm{OD}\right) \delta 159.0\left(\mathrm{~d}, J_{\mathrm{CF}}=6.6 \mathrm{~Hz}\right), 158.7\left(\mathrm{~d}, J_{\mathrm{CF}}=\right.$ $243.8 \mathrm{~Hz}), 134.4,129.4,119.2\left(\mathrm{~d}, J_{\mathrm{CF}}=14.5 \mathrm{~Hz}\right), 118.7,113.9\left(\mathrm{~d}, J_{\mathrm{CF}}=\right.$ $19.2 \mathrm{~Hz}$ ), 109.7, 70.9, 45.3, 18.4, 13.9, 13.1; HRMS (ESI) $\mathrm{m} / z$ calcd for $\mathrm{C}_{13} \mathrm{H}_{16} \mathrm{ClFNO}^{+}\left([\mathrm{M}+\mathrm{H}]^{+}\right): 256.0899$, found: $256.0901 ;[\alpha]_{\mathrm{D}}{ }^{20}+55.0$ (c $0.2, \mathrm{MeOH})$.

(-)-[2-[2-(Allyloxy)-4,5-dichlorophenyl]cyclopropyl]methanamine Hydrochloride ((-)-22e). White solid. HPLC: 99.1\%; ${ }^{1} \mathrm{H}$ NMR $\left(\mathrm{CD}_{3} \mathrm{OD}\right) \delta 7.12(\mathrm{~s}, 1 \mathrm{H}), 7.10(\mathrm{~s}, 1 \mathrm{H}), 6.17-6.07(\mathrm{~m}, 1 \mathrm{H})$, 5.47 (dd, $J=17.6,1.6 \mathrm{~Hz}, 1 \mathrm{H}), 5.34(\mathrm{dd}, J=10.4,1.6 \mathrm{~Hz}, 1 \mathrm{H}), 4.63$ $(\mathrm{d}, J=5.2 \mathrm{~Hz}, 2 \mathrm{H}), 3.08-2.97(\mathrm{~m}, 2 \mathrm{H}), 2.14-2.09(\mathrm{~m}, 1 \mathrm{H}), 1.37-1.32$ (m, $1 \mathrm{H}), 1.15-1.03(\mathrm{~m}, 2 \mathrm{H}) ;{ }^{13} \mathrm{C}$ NMR $\left(\mathrm{CD}_{3} \mathrm{OD}\right) \delta 157.9,134.3$, $131.9,131.4,129.2,124.7,118.7,115.0,70.9,44.9,19.4,17.9,13.5$; HRMS (ESI) $m / z$ calcd for $\mathrm{C}_{13} \mathrm{H}_{16} \mathrm{Cl}_{2} \mathrm{NO}^{+}\left([\mathrm{M}+\mathrm{H}]^{+}\right): 272.0603$, found: 272.0596 ; $[\alpha]_{\mathrm{D}}{ }^{20}-35.0(c 0.4, \mathrm{MeOH})$.

(+)-[2-[2-(Allyloxy)-4,5-dichlorophenyl]cyclopropyl]methanamine Hydrochloride ((+)-22e). White solid. HPLC: 99.2\%; 
${ }^{1} \mathrm{H}$ NMR $\left(\mathrm{CD}_{3} \mathrm{OD}\right) \delta 7.12(\mathrm{~s}, 1 \mathrm{H}), 7.10(\mathrm{~s}, 1 \mathrm{H}), 6.17-6.07(\mathrm{~m}, 1 \mathrm{H})$, $5.47(\mathrm{dd}, J=17.2,1.2 \mathrm{~Hz}, 1 \mathrm{H}), 5.34(\mathrm{~d}, J=10.4 \mathrm{~Hz}, 1 \mathrm{H}), 4.63(\mathrm{~d}, J=$ $5.2 \mathrm{~Hz}, 2 \mathrm{H}), 3.08-2.96(\mathrm{~m}, 2 \mathrm{H}), 2.14-2.09(\mathrm{~m}, 1 \mathrm{H}), 1.39-1.32(\mathrm{~m}$, $1 \mathrm{H}), 1.15-1.03(\mathrm{~m}, 2 \mathrm{H}) ;{ }^{13} \mathrm{C}$ NMR $\left(\mathrm{CD}_{3} \mathrm{OD}\right) \delta 157.9,134.3,131.9$, 131.4, 129.2, 124.7, 118.7, 115.0, 70.9, 44.9, 19.4, 17.9, 13.5; HRMS (ESI) $\mathrm{m} / z$ calcd for $\mathrm{C}_{13} \mathrm{H}_{16} \mathrm{Cl}_{2} \mathrm{NO}^{+}\left([\mathrm{M}+\mathrm{H}]^{+}\right): 272.0603$, found: 272.0597; $[\alpha]_{\mathrm{D}}^{20}+37.6(c 0.3, \mathrm{MeOH})$.

(-)-[2-[6-(Allyloxy)-2,3-dichlorophenyl]cyclopropyl]methanamine Hydrochloride ((-)-22f). White solid. HPLC: 98.3\%; ${ }^{1} \mathrm{H} \mathrm{NMR}\left(\mathrm{CD}_{3} \mathrm{OD}\right) \delta 7.37(\mathrm{~d}, J=9.2 \mathrm{~Hz}, 1 \mathrm{H}), 6.94(\mathrm{~d}, J=9.2 \mathrm{~Hz}, 1 \mathrm{H})$, $6.18-6.08(\mathrm{~m}, 1 \mathrm{H}), 5.46(\mathrm{dd}, J=17.2,1.6 \mathrm{~Hz}, 1 \mathrm{H}), 5.34(\mathrm{dd}, J=10.8$, $1.2 \mathrm{~Hz}, 1 \mathrm{H}), 4.62(\mathrm{~d}, J=5.2 \mathrm{~Hz}, 2 \mathrm{H}), 3.30(\mathrm{dd}, J=13.2,8.8 \mathrm{~Hz}, 1 \mathrm{H})$, $2.86(\mathrm{dd}, J=13.2,8.8 \mathrm{~Hz}, 1 \mathrm{H}), 1.83-1.77(\mathrm{~m}, 1 \mathrm{H}), 1.48-1.45(\mathrm{~m}, 1 \mathrm{H})$, $1.23-1.12(\mathrm{~m}, 2 \mathrm{H}) ;{ }^{13} \mathrm{C}$ NMR $\left(\mathrm{CD}_{3} \mathrm{OD}\right) \delta 158.8,135.9,134.4,130.0$, 129.9, 125.8, 118.9, 113.3, 70.9, 45.3, 20.2, 18.5, 15.3; HRMS (ESI) $\mathrm{m} / z$ calcd for $\mathrm{C}_{13} \mathrm{H}_{16} \mathrm{Cl}_{2} \mathrm{NO}^{+}\left([\mathrm{M}+\mathrm{H}]^{+}\right)$: 272.0603, found: 272.0611; $[\alpha]_{\mathrm{D}}{ }^{20}-68.0(c 0.1, \mathrm{MeOH})$.

(+)-[2-[6-(Allyloxy)-2,3-dichlorophenyl]cyclopropyl]methanamine Hydrochloride ((+)-22f). White solid. HPLC: $99.1 \% ;{ }^{1} \mathrm{H}$ NMR $\left(\mathrm{CD}_{3} \mathrm{OD}\right) \delta 7.37(\mathrm{~d}, J=8.8 \mathrm{~Hz}, 1 \mathrm{H}), 6.94(\mathrm{~d}, J=8.8 \mathrm{~Hz}, 1 \mathrm{H})$, 6.18-6.08 (m, 1H), $5.47(\mathrm{dd}, J=17.2,1.6 \mathrm{~Hz}, 1 \mathrm{H}), 5.34(\mathrm{dd}, J=10.4$, $1.2 \mathrm{~Hz}, 1 \mathrm{H}), 4.63(\mathrm{~d}, J=5.2 \mathrm{~Hz}, 2 \mathrm{H}), 3.30(\mathrm{dd}, J=12.8,8.8 \mathrm{~Hz}, 1 \mathrm{H})$, $2.86(\mathrm{dd}, J=12.8,8.8 \mathrm{~Hz}, 1 \mathrm{H}), 1.83-1.79(\mathrm{~m}, 1 \mathrm{H}), 1.48-1.46(\mathrm{~m}, 1 \mathrm{H})$, $1.23-1.15(\mathrm{~m}, 2 \mathrm{H}) ;{ }^{13} \mathrm{C}$ NMR $\left(\mathrm{CD}_{3} \mathrm{OD}\right) \delta 158.8,135.9,134.5,130.0$, $129.9,125.8,118.8,113.3,71.0,45.4,20.2,18.6,15.3$; HRMS (ESI) $\mathrm{m} / z$ calcd for $\mathrm{C}_{13} \mathrm{H}_{16} \mathrm{Cl}_{2} \mathrm{NO}^{+}\left([\mathrm{M}+\mathrm{H}]^{+}\right):$272.0603, found: 272.0596; $[\alpha]_{\mathrm{D}}^{20}+64.0(c 0.1, \mathrm{MeOH})$.

(-)-[2-[6-(Allyloxy)-2-chloro-3-fluorophenyl]cyclopropyl]methanamine Hydrochloride ((-)-22g). White solid. HPLC: 99.7\%; ${ }^{1} \mathrm{H} \mathrm{NMR}\left(\mathrm{CD}_{3} \mathrm{OD}\right) \delta 7.09(\mathrm{t}, J=8.8 \mathrm{~Hz}, 1 \mathrm{H}), 6.92(\mathrm{dd}, J=9.2,4.4 \mathrm{~Hz}$, $1 \mathrm{H}), 6.16-6.07(\mathrm{~m}, 1 \mathrm{H}), 5.46(\mathrm{dd}, J=17.6,1.6 \mathrm{~Hz}, 1 \mathrm{H}), 5.33(\mathrm{dd}, J=$ $10.6,1.4 \mathrm{~Hz}, 1 \mathrm{H}), 4.60(\mathrm{~d}, J=5.6 \mathrm{~Hz}, 2 \mathrm{H}), 3.29(\mathrm{dd}, J=13.2,6.4 \mathrm{~Hz}$, $1 \mathrm{H}), 2.87(\mathrm{dd}, J=12.8,8.6 \mathrm{~Hz}, 1 \mathrm{H}), 1.84-1.77(\mathrm{~m}, 1 \mathrm{H}), 1.53-1.47(\mathrm{~m}$, $1 \mathrm{H}), 1.22-1.17(\mathrm{~m}, 2 \mathrm{H}) ;{ }^{13} \mathrm{C} \mathrm{NMR}\left(\mathrm{CD}_{3} \mathrm{OD}\right) \delta 156.1,154.3\left(\mathrm{~d}, J_{\mathrm{CF}}=\right.$ $238.3 \mathrm{~Hz}), 134.7,129.5,124.5\left(\mathrm{~d}, J_{\mathrm{CF}}=18.2 \mathrm{~Hz}\right), 118.7,115.4\left(\mathrm{~d}, J_{\mathrm{CF}}=\right.$ $22.7 \mathrm{~Hz}), 112.8\left(\mathrm{~d}, J_{\mathrm{CF}}=7.5 \mathrm{~Hz}\right), 71.1,45.4,19.7,17.7,14.8$; HRMS (ESI) $\mathrm{m} / z$ calcd for $\mathrm{C}_{13} \mathrm{H}_{16} \mathrm{ClFNO}^{+}\left([\mathrm{M}+\mathrm{H}]^{+}\right): 256.0899$, found: 256.0895; $[\alpha]_{\mathrm{D}}{ }^{20}-52.0($ c $0.2, \mathrm{MeOH})$.

(+)-[2-[6-(Allyloxy)-2-chloro-3-fluorophenyl]cyclopropyl]methanamine Hydrochloride ((+)-22g). White solid. HPLC: 99.7\%; ${ }^{1} \mathrm{H} \mathrm{NMR}\left(\mathrm{CD}_{3} \mathrm{OD}\right) \delta 7.09(\mathrm{t}, J=8.8 \mathrm{~Hz}, 1 \mathrm{H}), 6.92(\mathrm{dd}, J=9.2,4.4 \mathrm{~Hz}$, $1 \mathrm{H}), 6.17-6.08(\mathrm{~m}, 1 \mathrm{H}), 5.46(\mathrm{dd}, J=17.6,1.6 \mathrm{~Hz}, 1 \mathrm{H}), 5.33(\mathrm{dd}, J=$ $10.4,1.2 \mathrm{~Hz}, 1 \mathrm{H}), 4.60(\mathrm{~d}, J=4.8 \mathrm{~Hz}, 2 \mathrm{H}), 3.29(\mathrm{dd}, J=13.6,6.0 \mathrm{~Hz}$, $1 \mathrm{H}), 2.87(\mathrm{dd}, J=12.8,8.8 \mathrm{~Hz}, 1 \mathrm{H}), 1.84-1.78(\mathrm{~m}, 1 \mathrm{H}), 1.53-1.47(\mathrm{~m}$, $1 \mathrm{H}), 1.21-1.17(\mathrm{~m}, 2 \mathrm{H}) ;{ }^{13} \mathrm{C} \mathrm{NMR}\left(\mathrm{CD}_{3} \mathrm{OD}\right) \delta 156.1,154.3\left(\mathrm{~d}, J_{\mathrm{CF}}=\right.$ $238.0 \mathrm{~Hz}), 134.7,129.5,124.5\left(\mathrm{~d}, J_{\mathrm{CF}}=18.1 \mathrm{~Hz}\right), 118.7,115.4\left(\mathrm{~d}, J_{\mathrm{CF}}=\right.$ $22.7 \mathrm{~Hz}), 112.8\left(\mathrm{~d}, J_{\mathrm{CF}}=6.6 \mathrm{~Hz}\right), 71.1,45.3,19.7,17.7,14.8$; HRMS (ESI) $m / z$ calcd for $\mathrm{C}_{13} \mathrm{H}_{16} \mathrm{ClFNO}^{+}\left([\mathrm{M}+\mathrm{H}]^{+}\right): 256.0899$, found: 256.0906; $[\alpha]_{\mathrm{D}}{ }^{20}+61.8(c 0.4, \mathrm{MeOH})$.

Calcium Flux Assay. Calcium flux assay was recorded on a FLIPR $^{\text {TETRA }}$ fluorescence imaging plate reader (Molecular Dynamics) on Flp-In-293 cells stably expressing the human $5-\mathrm{HT}_{2 \mathrm{~A}}, 5-\mathrm{HT}_{2 \mathrm{~B}}$, or $5-\mathrm{HT}_{2 \mathrm{C}-\mathrm{INI}}$ as previously described. ${ }^{23}$ For each experiment, 16 concentrations of the compound (from $3.3 \times 10^{-13}$ to $1 \times 10^{-5} \mathrm{M}$ based on a 3.3 $\times$ serial dilution) were tested to acquire a dose-response curve. Expression levels of the receptors were determined using saturation binding assays, $5-\mathrm{HT}_{2 \mathrm{~A}}: 1200 \mathrm{fmol} / \mathrm{mg}\left({ }^{3} \mathrm{H}\right.$-ketanserin, $\left.K_{\mathrm{d}}=1.6 \mathrm{nM}\right)$, $5-\mathrm{HT}_{2 \mathrm{~B}}: 500 \mathrm{fmol} / \mathrm{mg}\left({ }^{3} \mathrm{H}\right.$-lysergic acid diethylamide (LSD), $K_{\mathrm{d}}=$ $2.2 \mathrm{nM})$, and $5-\mathrm{HT}_{2 \mathrm{C}}: 1800 \mathrm{fmol} / \mathrm{mg}\left({ }^{3} \mathrm{H}\right.$-mesulergine, $\left.K_{\mathrm{d}}=4.5 \mathrm{nM}\right)$.

Off-Target Screening of Compound (+)-22a by the National Institute of Mental Health's Psychoactive Drug Screening Program (NIMH PDSP). Primary binding experiments were performed at $10 \mu \mathrm{M}$ for compound (+)-22a, and the percentage displacement of the radioligand was measured. Targets showing $>50 \%$ inhibition of binding at $10 \mu \mathrm{M}$ were selected for full concentration-response competitive binding experiments, and binding constants $\left(K_{\mathrm{i}}\right)$ were determined. For experimental details, refer to the PDSP Web site: http://pdspdb.unc.edu/pdspWeb/.
ADMET Tests. The liver microsomal stability study, brain penetration test, cytochrome P450 inhibition test, and hERG inhibition study were conducted by Pharmaron, Inc. (Beijing, China).

Animal Behavioral Methods. Animals. Adult male and female C57BL/6J (Jackson Laboratories, Bar Harbor, ME) and NR1 mice were used for behavioral testing. All mice were between 14-18 weeks of age at the time of testing. Mice were maintained on a $14 \mathrm{~h}$ light $/ 10 \mathrm{~h}$ dark light-dark cycle with the onset of the dark cycle at $2000 \mathrm{~h}$. Testing was conducted during the light cycle between 1000-1600 h. All animals were housed by genotype and sex. Forty-eight hours before testing, mice were weighed and moved into the appropriate test room. Mice remained in the test room for the duration of testing and had ad libitum access to food and water. All studies were conducted with an approved protocol from the Duke University Institutional Animal Care and Use Committee.

Drugs. Haloperidol (Sigma-Aldrich, St. Louis MO) and compound $(+)-22 \mathrm{a}$ were dissolved in $0.5 \% \mathrm{~N}, \mathrm{~N}$-dimethylacetamide and $10 \%$ (2-hydroxypropyl)- $\beta$-cyclodextrin in sterile saline. $d$-Amphetamine (AMPH; Tocris Bioscience, Bristol, UK) was dissolved in sterile saline. All treatments were delivered in a $4 \mathrm{~mL} / \mathrm{kg}$ volume (ip).

Open Field Activity. Activity in the open field was assessed as distance traveled in a novel environment $(20 \times 20 \times 20 \mathrm{~cm})$ using a Versamax Analyzer system (Omnitech Electronics, Columbus, $\mathrm{OH}$ ). Locomotor activity was monitored by infrared diodes interfaced to a computer running Fusion software (Omnitech Electronics). C57BL/6J mice ( $n=7-10$ mice/treatment) were injected with vehicle (Veh) or 2, 5, 10, 20 , or $30 \mathrm{mg} / \mathrm{kg}$ compound (+)-22a and placed into the open field. After $15 \mathrm{~min}$, each animal was removed and given Veh or $3 \mathrm{mg} / \mathrm{kg}$ AMPH and returned immediately to the open field for an additional $105 \mathrm{~min}$. Controls consisted of separate groups of mice administered Veh-Veh or $20 \mathrm{mg} / \mathrm{kg}$ compound (+)-22a + Veh. The results are depicted as total distance traveled in $5 \mathrm{~min}$ intervals over testing or cumulative distance traveled over the $15 \mathrm{~min}$ of baseline and $75 \mathrm{~min}$ following injection of AMPH or the vehicle.

Prepulse Inhibition. Prepulse inhibition (PPI) was assessed using the SR Startle Lab Response system for mice (San Diego Instruments, San Diego, CA). Adult C57BL/6J males ( $n=8-11$ mice/treatment group) were administered the Veh or $0.5,1,2$, or $4 \mathrm{mg} / \mathrm{kg}$ compound (+)-22a followed $10 \mathrm{~min}$ later with Veh or $3 \mathrm{mg} / \mathrm{kg}$ AMPH. Mice were placed into a Plexiglas holder which was positioned into the test chamber that was interfaced to a computer running SR Lab Startle Reflex software. ${ }^{47}$ After a 10 min acclimatization period, mice were exposed to 42 test trials composed of 18 pulse-only trials, 18 prepulse-pulse trials, and 6 null trials. A $62 \mathrm{~dB}$ white noise background was present during testing. Pulseonly trials consisted of a single $40 \mathrm{~ms} 120 \mathrm{~dB}$ burst of white noise. Prepulse-pulse trials consisted of a $20 \mathrm{~ms}$ prepulse of white noise that was 4,8 , or $12 \mathrm{~dB}$ above the $62 \mathrm{~dB}$ background, followed $100 \mathrm{~ms}$ later with the $120 \mathrm{~dB}$ pulse. The white noise background was the only stimulus present during the null only trials. Testing began and ended with a block of five pulse-only trials; the remaining pulse-only trials were randomized with the null trials and the prepulse-pulse trials between these two blocks of pulse-only trials. The percent PPI for each prepulse intensity was calculated as the ratio of the average response during the prepulse-pulse trials to the average pulse-only responses, subtracted from 1 , multiplied by 100 , and expressed as a percentage. Null activity and pulse-only responses are reported in arbitrary units (AU) as measured by the SR Startle Lab Response system. The peak of the startle response (AU) was measured within a $65 \mathrm{~ms}$ window following onset of the pulse-only stimulus. ${ }^{48}$

Novel Object Recognition Memory. Wild type (WT) and NR1-KD mice ( $n=9-10$ mice/genotype/treatment) were randomly assigned to three treatment groups that received Veh or 0.5 or $1 \mathrm{mg} / \mathrm{kg}$ compound (+)-22a. Testing was conducted over 3 days with a single trial $(5 \mathrm{~min})$ on each day. ${ }^{47}$ Mice were acclimated to the empty test chambers $(38 \times$ $22 \times 20 \mathrm{~cm}$ ) on day 1 and exposed to two identical objects on day 2 . Twenty-four hours later, mice were presented with one of the same objects from day 2 which was paired with a novel object to evaluate longterm memory (LTM). Mice were administered Veh or compound (+)-22a 30 min prior to the trials on days 2 and 3. All trials were videorecorded using the Noldus Media Recorder (Noldus Technologies, 
Wageningen, Netherlands), and behavioral data were analyzed using Noldus Ethovision 10. Duration of time spent investigating the objects was scored. The results are presented as preference scores; object preference $=($ time spent with novel object-time spent with familiar object)/total time with both objects. Positive scores denote preference for the novel object, negative scores signify preference for the familiar object, and scores approaching zero indicate no preference for either object.

Catalepsy. Male C57BL/6J mice $(n=8-10$ mice/treatment/timepoint) were assessed for cataleptic responses. Baseline cataleptic responses were assessed following removal from the home-cage by placing both front paws on a $60 \mathrm{~cm}$ horizontal bar $(2.5 \mathrm{~mm}$ diameter $)$ elevated above the bench with both rear paws in direct contact with the bench. Immediately following the baseline assessment, each animal was injected with vehicle, haloperidol, or compound (+)-22a and returned to its home cage. Catalepsy was evaluated in separate groups of mice at $60 \mathrm{~min}$. The time spent in catalepsy was measured as the time following placement to removal of the front paws from the bar, with a maximum cutoff time of $60 \mathrm{~s}$.

Statistics. All data were analyzed using SPSS 22 (IBM SPSS, Chicago, $\mathrm{IL}$ ) and are presented as means and standard errors of the mean (SEM). Distance traveled in the open field was assessed with RMANOVA with time as the within subjects effect and treatment condition as the between subjects effect. For PPI, null and startle activities were assessed using ANOVA with treatment as the between subjects variable. Differences in PPI were examined with RMANOVA with prepulse intensity as the within subjects variable and treatment condition as the between subjects variable. Responses in NORM were evaluated using ANOVA for preference scores in the LTM test with genotype and treatment as independent variables. Duration of contact with the objects during the training session and the LTM test were analyzed with RMANOVA using test-session as the within subjects variable and genotype and treatment as the between subjects variables. For time spent in catalepsy, a one-way ANOVA was performed examining the effects of treatment. Posthoc comparisons were performed with Bonferroni corrected pairwise comparisons for all analyses. In all cases, a $p<0.05$ was considered significant.

\section{ASSOCIATED CONTENT}

\section{S Supporting Information}

The Supporting Information is available free of charge on the ACS Publications website at DOI: 10.1021/acs.jmedchem.5b01153.

Synthetic procedures for compounds $16 \mathbf{a}-\mathrm{g}, 18 \mathrm{a}-\mathrm{g}$, and $19 \mathrm{a}-\mathrm{g}$, and characterization data of all chemical intermediates (PDF)

Molecular formula strings of compounds $(-)-20 a-g$, $(+)-20 a-g,(-)-21 a-g,(+)-21 a-g,(-)-22 a-g$, and $(+)-22 \mathbf{a}-\mathbf{g}(\mathrm{CSV})$

\section{AUTHOR INFORMATION}

\section{Corresponding Author}

*Telephone: +1 312 996-7577. E-mail: kozikowa@uic.edu.

\section{Present Addresses}

"Department of Biochemistry, Microbiology and Immunology, University of Ottawa, Ottawa, ON, K1H 8M5, Canada.

${ }^{\#}$ Catalent Pharma Solutions, 160N Pharma Dr., Morrisville, NC 27560.

\section{Notes}

The authors declare no competing financial interest.

\section{ACKNOWLEDGMENTS}

Financial support from the National Institute of Mental Health (NIMH) (no. R01MH99993) and Psychoactive Drug Screening Program (PDSP, Contract no. HHSN-271-2013-00017-C) is gratefully acknowledged. We thank Dr. Werner Tueckmantel for proofreading the manuscript and providing valuable suggestions.

\section{ABBREVIATIONS USED}

5-HT, serotonin; ADMET, absorption, distribution, metabolism, excretion and toxicity; AMPH, $d$-amphetamine; BBB, bloodbrain barrier; CNS, central nervous system; CYP, cytochrome; EPS, extrapyramidal symptoms; FDA, US Food and Drug Administration; GPCR, G-protein coupled receptor; HEK-293, human embryonic kidney 293 cells; hERG, human ether-à-gogo-related gene; HPLC, high-performance liquid chromatography; KD, knockdown; LTM, long-term memory; NMDA, $N$ methyl-D-aspartate; NORM, novel object recognition memory; PPI, prepulse inhibition; SAR, structure-activity relationship; Tph2, tryptophan hydroxylase 2; Veh, vehicle; WT, wild type

\section{REFERENCES}

(1) http://www.who.int/mental_health/management/ schizophrenia/en/.

(2) Schizophrenia Working Group of the Psychiatric Genomics Consortium. Biological insights from 108 schizophrenia-associated genetic loci. Nature 2014, 511, 421-427.

(3) Gray, J. A.; Roth, B. L. The pipeline and future of drug development in schizophrenia. Mol. Psychiatry 2007, 12, 904-922.

(4) Harvey, P. D.; Keefe, R. S. E. Studies of cognitive change in patients with schizophrenia following novel antipsychotic treatment. Am. J. Psychiatry 2001, 158, 176-184.

(5) Goldberg, T. E.; Goldman, R. S.; Burdick, K. E.; Malhotra, A. K.; Lencz, T.; Patel, R. C.; Woerner, M. G.; Schooler, N. R.; Kane, J. M.; Robinson, D. G. Cognitive improvement after treatment with secondgeneration antipsychotic medications in first-episode schizophrenia - Is it a practice effect? Arch. Gen. Psychiatry 2007, 64, 1115-1122.

(6) Meltzer, H. Y.; Roth, B. L. Lorcaserin and pimavanserin: Emerging selectivity of serotonin receptor subtype-targeted drugs. J. Clin. Invest. 2013, 123, 4986-4991.

(7) Berger, M.; Gray, J. A.; Roth, B. L. The expanded biology of serotonin. Annu. Rev. Med. 2009, 60, 355-366.

(8) ClinicalTrials.gov Identifier: NCT02044874.

(9) ClinicalTrials.gov Identifier: NCT00563706.

(10) Shen, J. H.; Zhao, Y.; Rosenzweig-Lipson, S.; Popp, D.; Williams, J. B.; Giller, E.; Detke, M. J.; Kane, J. M. A 6-week randomized, doubleblind, placebo-controlled, comparator referenced trial of vabicaserin in acute schizophrenia. J. Psychiatr. Res. 2014, 53, 14-22.

(11) Lee, M. A.; Jayathilake, K.; Sim, M. Y.; Meltzer, H. Y. Decreased serotonin $_{2 \mathrm{C}}$ receptor responses in male patients with schizophrenia. Psychiatry Res. 2015, 226, 308-315.

(12) Huang, M.; Dai, J.; Meltzer, H. Y. 5- $\mathrm{HT}_{2 \mathrm{~A}}$ and 5- $\mathrm{HT}_{2 \mathrm{C}}$ receptor stimulation are differentially involved in the cortical dopamine effluxstudied in $5-\mathrm{HT}_{2 \mathrm{~A}}$ and $5-\mathrm{HT}_{2 \mathrm{C}}$ genetic mutant mice. Eur. J. Pharmacol. 2011, 652, 40-45.

(13) Rauser, L.; Savage, J. E.; Meltzer, H. Y.; Roth, B. L. Inverse agonist actions of typical and atypical antipsychotic drugs at the human 5hydroxytryptamine ${ }_{2 C}$ receptor. J. Pharmacol. Exp. Ther. 2001, 299, 83-89.

(14) Kroeze, W. K.; Hufeisen, S. J.; Popadak, B. A.; Renock, S.; Steinberg, S. A.; Ernsberger, P.; Jayathilake, K.; Meltzer, H. Y.; Roth, B. L. $\mathrm{H}_{1}$-histamine receptor affinity predicts short-term weight gain for typical and atypical antipsychotic drugs. Neuropsychopharmacology 2003, 28, 519-526.

(15) Marquis, K. L.; Sabb, A. L.; Logue, S. F.; Brennan, J. A.; Piesla, M. J.; Comery, T. A.; Grauer, S. M.; Ashby, C. R.; Nguyen, H. Q.; Dawson, L. A.; Barrett, J. E.; Stack, G.; Meltzer, H. Y.; Harrison, B. L.; Rosenzweig-Lipson, S. WAY-163909 [(7bR, 10aR)-1,2,3,4,8,9,10,10aoctahydro-7bH-cyclopenta[b] $[1,4]$ diazepino $[6,7,1 \mathrm{hi}]$ indole $]$ : A novel 5-hydroxytryptamine $2 \mathrm{C}$ receptor-selective agonist with preclinical antipsychotic-like activity. J. Pharmacol. Exp. Ther. 2007, 320, 486-496.

(16) Musil, R.; Obermeier, M.; Russ, P.; Hamerle, M. Weight gain and antipsychotics: A drug safety review. Expert Opin. Drug Saf. 2015, 14, 73-96.

(17) Calcagno, E.; Carli, M.; Baviera, M.; Invernizzi, R. W. Endogenous serotonin and $\operatorname{serotonin}_{2 \mathrm{C}}$ receptors are involved in the ability of 
M100907 to suppress cortical glutamate release induced by NMDA receptor blockade. J. Neurochem. 2009, 108, 521-532.

(18) Del'Guidice, T.; Lemay, F.; Lemasson, M.; Levasseur-Moreau, J.; Manta, S.; Etievant, A.; Escoffier, G.; Dore, F. Y.; Roman, F. S.; Beaulieu, J. M. Stimulation of $5-\mathrm{HT}_{2 \mathrm{C}}$ receptors improves cognitive deficits induced by human tryptophan hydroxylase 2 loss of function mutation. Neuropsychopharmacology 2014, 39, 1125-1134.

(19) Nichols, D. E. Hallucinogens. Pharmacol. Ther. 2004, 101, 131-181. (20) Rothman, R. B.; Baumann, M. H.; Savage, J. E.; Rauser, L.; McBride, A.; Hufeisen, S. J.; Roth, B. L. Evidence for possible involvement of $5-\mathrm{HT}_{2 \mathrm{~B}}$ receptors in the cardiac valvulopathy associated with fenfluramine and other serotonergic medications. Circulation 2000, $102,2836-2841$.

(21) Thomsen, W. J.; Grottick, A. J.; Menzaghi, F.; Reyes-Saldana, H.; Espitia, S.; Yuskin, D.; Whelan, K.; Martin, M.; Morgan, M.; Chen, W.; Al-Shamma, H.; Smith, B.; Chalmers, D.; Behan, D. Lorcaserin, a novel selective human 5-hydroxytryptamine ${ }_{2 \mathrm{C}}$ agonist: In vitro and in vivo pharmacological characterization. J. Pharmacol. Exp. Ther. 2008, 325, 577-587.

(22) DiNicolantonio, J. J.; Chatterjee, S.; O’Keefe, J. H.; Meier, P. Lorcaserin for the treatment of obesity? A closer look at its side effects. Open Heart 2014, 1, e000173.

(23) Cheng, J.; Giguere, P. M.; Onajole, O. K.; Lv, W.; Gaisin, A.; Gunosewoyo, H.; Schmerberg, C. M.; Pogorelov, V. M.; Rodriguiz, R. M.; Vistoli, G.; Wetsel, W. C.; Roth, B. L.; Kozikowski, A. P. Optimization of 2-phenylcyclopropylmethylamines as selective seroto$\operatorname{nin} 2 \mathrm{C}$ receptor agonists and their evaluation as potential antipsychotic agents. J. Med. Chem. 2015, 58, 1992-2002.

(24) Chen, G.; Cho, S. J.; Huang, X. P.; Jensen, N. H.; Svennebring, A.; Sassano, M. F.; Roth, B. L.; Kozikowski, A. P. Rational drug design leading to the identification of a potent $5-\mathrm{HT}_{2 \mathrm{C}}$ agonist lacking $5-\mathrm{HT}_{2 \mathrm{~B}}$ Activity. ACS Med. Chem. Lett. 2011, 2, 929-932.

(25) Kozikowski, A. P.; Cho, S. J.; Jensen, N. H.; Allen, J. A.; Svennebring, A. M.; Roth, B. L. HTS and rational drug design to generate a class of $5-\mathrm{HT}_{2 \mathrm{C}}$-selective ligands for possible use in schizophrenia. ChemMedChem 2010, 5, 1221-1225.

(26) Cho, S. J.; Jensen, N. H.; Kurome, T.; Kadari, S.; Manzano, M. L.; Malberg, J. E.; Caldarone, B.; Roth, B. L.; Kozikowski, A. P. Selective 5hydroxytryptamine $2 \mathrm{C}$ receptor agonists derived from the lead compound tranylcypromine: Identification of drugs with antidepressant-like action. J. Med. Chem. 2009, 52, 1885-1902.

(27) Hagmann, W. K. The many roles for fluorine in medicinal chemistry. J. Med. Chem. 2008, 51, 4359-4369.

(28) Kim, D.; Wang, L.; Beconi, M.; Eiermann, G. J.; Fisher, M. H.; He, H.; Hickey, G. J.; Kowalchick, J. E.; Leiting, B.; Lyons, K.; Marsilio, F.; McCann, M. E.; Patel, R. A.; Petrov, A.; Scapin, G.; Patel, S. B.; Roy, R. S.; Wu, J. K.; Wyvratt, M. J.; Zhang, B. B.; Zhu, L.; Thornberry, N. A.; Weber, A. E. (2R)-4-Oxo-4-[3-(trifluoromethyl)-5,6-dihydro[1,2,4]triazolo[4,3-a]pyrazin-7(8H)- yl]-1-(2,4,5-trifluorophenyl)butan-2amine: A potent, orally active dipeptidyl peptidase IV inhibitor for the treatment of type 2 diabetes. J. Med. Chem. 2005, 48, 141-151.

(29) Cui, J. J.; Tran-Dube, M.; Shen, H.; Nambu, M.; Kung, P. P.; Pairish, M.; Jia, L.; Meng, J.; Funk, L.; Botrous, I.; McTigue, M.; Grodsky, N.; Ryan, K.; Padrique, E.; Alton, G.; Timofeevski, S.; Yamazaki, S.; Li, Q.; Zou, H.; Christensen, J.; Mroczkowski, B.; Bender, S.; Kania, R. S.; Edwards, M. P. Structure-based drug design of crizotinib (PF-02341066), a potent and selective dual inhibitor of mesenchymalepithelial transition factor (c-MET) kinase and anaplastic lymphoma kinase (ALK). J. Med. Chem. 2011, 54, 6342-6363.

(30) Lawler, C. P.; Prioleau, C.; Lewis, M. M.; Mak, C.; Jiang, D.; Schetz, J. A.; Gonzalez, A. M.; Sibley, D. R.; Mailman, R. B. Interactions of the novel antipsychotic aripiprazole (OPC-14597) with dopamine and serotonin receptor subtypes. Neuropsychopharmacology 1999, 20, $612-627$.

(31) Wilcken, R.; Zimmermann, M. O.; Lange, A.; Joerger, A. C.; Boeckler, F. M. Principles and applications of halogen bonding in medicinal chemistry and chemical biology. J. Med. Chem. 2013, 56, $1363-1388$.
(32) Voth, A. R.; Khuu, P.; Oishi, K.; Ho, P. S. Halogen bonds as orthogonal molecular interactions to hydrogen bonds. Nat. Chem. 2009, 1, 74-79.

(33) Toy, P. H.; Dhanabalasingam, B.; Newcomb, M.; Hanna, I. H.; Hollenberg, P. F. A substituted hypersensitive radical probe for enzymecatalyzed hydroxylations: Synthesis of racemic and enantiomerically enriched forms and application in a cytochrome P450-catalyzed oxidation. J. Org. Chem. 1997, 62, 9114-9122.

(34) Gooden, D. M.; Schmidt, D. M. Z.; Pollock, J. A.; Kabadi, A. M.; McCafferty, D. G. Facile synthesis of substituted trans-2-arylcyclopropylamine inhibitors of the human histone demethylase LSD1 and monoamine oxidases A and B. Bioorg. Med. Chem. Lett. 2008, 18, 30473051.

(35) Besnard, J.; Ruda, G. F.; Setola, V.; Abecassis, K.; Rodriguiz, R. M.; Huang, X. P.; Norval, S.; Sassano, M. F.; Shin, A. I.; Webster, L. A.; Simeons, F. R. C.; Stojanovski, L.; Prat, A.; Seidah, N. G.; Constam, D. B.; Bickerton, G. R.; Read, K. D.; Wetsel, W. C.; Gilbert, I. H.; Roth, B. L.; Hopkins, A. L. Automated design of ligands to polypharmacological profiles. Nature 2012, 492, 215-220.

(36) Benhamu, B.; Martin-Fontecha, M.; Vazquez-Villa, H.; Pardo, L.; Lopez-Rodriguez, M. L. Serotonin $5-\mathrm{HT}_{6}$ receptor antagonists for the treatment of cognitive deficiency in Alzheimer's disease. J. Med. Chem. 2014, 57, 7160-7181.

(37) Karila, D.; Freret, T.; Bouet, V.; Boulouard, M.; Dallemagne, P.; Rochais, C. Therapeutic potential of 5- $\mathrm{HT}_{6}$ receptor agonists. J. Med. Chem. 2015, 58, 7901-7912.

(38) Aronov, A. M. Predictive in silico modeling for hERG channel blockers. Drug Discovery Today 2005, 10, 149-155.

(39) Allen, J. A.; Yost, J. M.; Setola, V.; Chen, X.; Sassano, M. F.; Chen, M.; Peterson, S.; Yadav, P. N.; Huang, X. P.; Feng, B.; Jensen, N. H.; Che, X.; Bai, X.; Frye, S. V.; Wetsel, W. C.; Caron, M. G.; Javitch, J. A.; Roth, B. L.; Jin, J. Discovery of beta-arrestin-biased dopamine $\mathrm{D}_{2}$ ligands for probing signal transduction pathways essential for antipsychotic efficacy. Proc. Natl. Acad. Sci. U. S. A. 2011, 108, 18488-18493.

(40) Chitty, K.; Albrecht, M. A.; Graham, K.; Kerr, C.; Lee, J. W. Y.; Iyyalol, R.; Martin-Iverson, M. T. Dexamphetamine effects on prepulse inhibition (PPI) and startle in healthy volunteers. Psychopharmacology 2014, 231, 2327-2337.

(41) Ramsey, A. J. NR1 knockdown mice as a representative model of the glutamate hypothesis of schizophrenia. Prog. Brain Res. 2009, 179, $51-58$.

(42) Danion, J. M.; Huron, C.; Vidailhet, P.; Berna, F. Functional mechanisms of episodic memory impairment in schizophrenia. Can. J. Psychiatry 2007, 52, 693-701.

(43) Horiguchi, M.; Meltzer, H. Y. The role of 5- $\mathrm{HT}_{1 \mathrm{~A}}$ receptors in phencyclidine (PCP)-induced novel object recognition (NOR) deficit in rats. Psychopharmacology (Berl) 2012, 221, 205-215.

(44) Miller, K. J.; Wu, G. Y.; Varnes, J. G.; Levesque, P.; Li, J. L.; Li, D. S.; Robl, J. A.; Rossi, K. A.; Wacker, D. A. Position 5.46 of the serotonin $5-\mathrm{HT}_{2 \mathrm{~A}}$ receptor contributes to a species-dependent variation for the 5$\mathrm{HT}_{2 \mathrm{C}}$ agonist (R)-9-ethyl-1,3,4,10b-tetrahydro-7trifluoromethylpyrazino[2,1-a]isoindol-6 $(2 \mathrm{H})$-one: impact on selectivity and toxicological evaluation. Mol. Pharmacol. 2009, 76, 1211-1219.

(45) Sipes, T. E.; Geyer, M. A. DOI disrupts prepulse inhibition of startle in rats via $5-\mathrm{HT}_{2 \mathrm{~A}}$ receptors in the ventral pallidum. Brain Res. 1997, 761, 97-104.

(46) Jensen, N. H.; Rodriguiz, R. M.; Caron, M. G.; Wetsel, W. C.; Rothman, R. B.; Roth, B. L. N-Desalkylquetiapine, a potent norepinephrine reuptake inhibitor and partial $5-\mathrm{HT}_{1 \mathrm{~A}}$ agonist, as a putative mediator of quetiapine's antidepressant activity. Neuropsychopharmacology 2008, 33, 2303-2312.

(47) Park, S. M.; Chen, M.; Schmerberg, C. M.; Dulman, R. S.; Rodriguiz, R. M.; Caron, M. G.; Jin, J.; Wetsel, W. C. Effects of $\beta$-arrestin biased dopamine $\mathrm{D}_{2}$ receptor ligands on schizophrenia-like behavior in hypoglutmatergic mice. Neuropsychopharmacology 2015, in press, 10.1038/npp.2015.196.

(48) Geyer, M. A.; Swerdlow, N. R. Measurement of startle response, prepulse inhibition, and habituation. Current Protocols in Neuroscience; Wiley: Hoboken, NJ, 2001; Chapter 8, 8.7.1-8.7.15. 